\title{
Effect of therapies-mediated modulation of telomere and/or telomerase on cancer cells radiosensitivity
}

\author{
Ganiou Assani ${ }^{1,2,3}$, Yudi Xiong ${ }^{1,2,3}$, Fuxiang Zhou ${ }^{1,2,3}$ and Yunfeng Zhou ${ }^{1,2,3}$ \\ ${ }^{1}$ Department of Radiation and Medical Oncology, Zhongnan Hospital of Wuhan University, Wuhan, China \\ ${ }^{2}$ Hubei Cancer Clinical Study Center, Zhongnan Hospital of Wuhan University, Wuhan, China \\ ${ }^{3}$ Hubei Key Laboratory of Tumor Biology Behaviors, Zhongnan Hospital of Wuhan University, Wuhan, China \\ Correspondence to: Yunfeng Zhou, email: yfzhouwhu@163.com \\ Keywords: cancer cells; telomere; telomerase; radiosensitivity; radiotherapy \\ Received: May 29, $2018 \quad$ Accepted: July 31, $2018 \quad$ Published: October 09, 2018 \\ Copyright: Assani et al. This is an open-access article distributed under the terms of the Creative Commons Attribution License 3.0 \\ (CC BY 3.0), which permits unrestricted use, distribution, and reproduction in any medium, provided the original author and source \\ are credited.
}

\section{ABSTRACT}

Cancer is one of the leading causes of death in the world. Many strategies of cancer treatment such as radiotherapy which plays a key role in cancer treatment are developed and used nowadays. However, the side effects post-cancer radiotherapy and cancer radioresistance are two major causes of the limitation of cancer radiotherapy effectiveness in the cancer patients. Moreover, reduction of the limitation of cancer radiotherapy effectiveness by reducing the side effects postcancer radiotherapy and cancer radioresistance is the aim of several radiotherapyoncologic teams. Otherwise, Telomere and telomerase are two cells components which play an important role in cancer initiation, cancer progression and cancer therapy resistance such as radiotherapy resistance. For resolving the problems of the limitation of cancer radiotherapy effectiveness especially the cancer radio-resistance problems, the radio-gene-therapy strategy which is the use of gene-therapy via modulation of gene expression combined with radiotherapy was developed and used as a new strategy to treat the patients with cancer. In this review, we summarized the information concerning the implication of telomere and telomerase modulation in cancer radiosensitivity.

\section{INTRODUCTION}

Cancer was the second leading cause of death worldwide after cardiovascular diseases [1]. In 2015, 17.5 million cancer case and 8.7 million of death were found. Cancer caused 14\% of deaths in 2005 against 16\% in 2015 and the number is predicted to be increased in the future. Based on the data enumerated above, cancer can be considered as an important public health which needs the strong strategies of management for its prevention and its treatment. Moreover, many kinds of strategies of treatment such as chemotherapy [2], immunotherapy [3], genetherapy [4], nanotherapy [5], radiotherapy [6], phytotherapy [7] have been developed and used to treat cancer. Among all strategies mentioned above, Radiotherapy seems more important because, in many countries, more than $50 \%$ of new cases of cancer received at least one course of radiotherapy during their lifetime $[8,9]$. Although the effectiveness of radiotherapy of cancer is not negligible, radiotherapy efficacy has a limitation such as the development of radioresistance by many types of cancer [10] and occurrence of the side effects postcancer radiotherapy [11]. Reduction of the limitation of the cancer radiotherapy efficacy via a better understanding of the mechanisms of development of radioresistance for cancer radioresistance reduction and/or decreasing of occurrence of side effects post-cancer radiotherapy is today, the main goal for many research teams of oncoradiotherapy.

Telomere and telomerase are molecular biomarkers and constitute of one of the systems implicated in sensitization of cancer to irradiation. Telomere is the prognostic and the predictive marker for stratifying patients for their post-treatment follow-up [12]. As a 
rational approach based on the unique role of telomerase in the cancer cell biology [13], modulation of telomere or telomerase before cancer cell irradiation reduce the limitation of cancer radiotherapy efficacy can modulates cancer radiosensitivity and the occurrence of the side effects post-cancer radiotherapy which in general, depends on many factors concerning irradiation and cancer cells or tumor tissues [14]. Based on the goal which is the reduction of the limitation of cancer radiotherapy effectiveness via especially, the understanding of how telomere and/or telomerase are implicated in radiosensitivity for radiosensitivity enhancing, we summarized many articles in which modulation of telomere or telomerase before irradiation affects cancer cells radiosensitivity which supposed to be implicated in the management of limitation of cancer radiotherapy efficacy.

\section{TELOMERE AND TELOMERASE IN NORMAL AND CANCER CELL}

\section{Telomere and telomerase in the normal cell}

Telomere is the nucleoprotein structure composed of guanine-rich conserved DNA which varies in length, sequence and number of repeats. It is showed as protector of the end of the chromosome and is discovered, for the first time, in the flies and maize $[15,16]$. In mammalian species, telomere is composed of TTAGGC repeat tracks that terminated in a single-stranded G-rich $3^{\prime}$ overhang [17-20]. The single-stranded (ss) DNA product is a few hundred nucleotides whereas the length of double-stranded (ds) telomere tracks is around $9-15 \mathrm{~Kb}[21,22]$. Telomere also exists in a secondary structure called T-loop formed by the invasion of $3^{\prime}$ overhang into the duplex region. This is associated with protective proteins termed shelterin complex which stabilized T-loop and regulated telomere stability and homeostasis [23-26]. The shelterin complex consists of Telomere Repeat Factor1 (TRF1), Telomere Repeat Factor2 (TRF2), Repressor Activated Protein (Rap1), Protection of Telomere (POP1), TripeptidylPeptidase 1(TPP1), TRF1 and TRF2 interacting Nuclear Protein2 (Tin2) which provide protection against DNA damage signals, DNA recombination or DNA end-joining processes [23]. Sheltering complex assures its function by specifically and directly binding to the telomere. TRF1 and TRF2 bind to ds DNA [27-29] whereas POT1 binds to ss-DNA $[30,31]$ through sequence recognition., Tin2 links to TRF1, TRF2 links to Tin2 by Protein-Protein interaction, TPP1 binds to POT1 and TRF2 to Rap1 $[32,33]$. The interaction TRF1-TRF2 and POT1-TPP1 at telomere DNA are consolidated by Tin2 (Figure 1). In addition to shelterin complex, the Conserved Telomere maintenance Complex1 (CTC1), Suppressor of cdc13 1 (STN1) and telomeric pathways with STN1 (TEN1) contributed to telomere homeostasis. The telomere CTC1/
STN1/TEN1 (CST) acts on telomere as a composite and functions in the replication and processing of telomere prior to affecting telomerase action. Protection effect of telomere is characterized by providing mechanism to compensate the under replication of the end of linear DNA molecule, by keeping true chromosome ends from fusing with other chromosome ends or with broken chromosome to make chimerics chromosomes, by distinguishing true chromosome ends from breaks DNA and by controlling the position of chromosome within the nucleus [34]. Moreover, the transcriptional silence of genes located close to telomere via TPE phenomenon [35], transcriptional modulation of gene at a long distance from telomere such as telomerase via TPE-OLD mechanism $[36,37]$, the ensuring right chromosome segregation during mitosis and definition of the number of the cell cycle, via cell cycle regulation, that a cell may undergo during its life are also the roles of telomere [28, 38-40]. In somatic cells, because of the gap between final RNA primer and end of the chromosome cannot be completed, telomere shortens after each cell division [41] with loss of 100 to 200 bases of telomere DNA per cell division [42-44]. When telomeres become critically shorten, cells undergo in a senescent state "Hayflick Limit" where cells can live for years without division [45]. Telomere length is majority regulated by telomerase activity and rarely, by Alternative Lengthening of Telomere (ALT) mechanism [46].

Telomerase is a special ribonucleoprotein enzyme which maintains telomere by neutralizing the lost of telomeric repeats at the 3' telomeric overhang. Discovered for the first time in Tetrahymena [47], telomerase is minimally composed by a Telomerase Reverse Transcriptase(TERT), RNA Template or Telomerase RNA component (TERC) and stabilizing proteins which including dyskerin (DCK1) and TCHB1 $[23,48]$. Telomerase activity maintains telomere length but not totally prevents telomere attrition [49-52]. The mechanism of action of telomerase can be divided into three steps. In the first step, the 3'matrix end of the chromosome of the short telomere binds to RNA domain, in the second step, occurrence of elongation which is a direct addition of nucleotide and last step, translocation which enables repeated use of the same binding site [53-61]. The human Telomerase Reverse Transcriptase (hTERT) catalytic subunit is a polypeptide which consists of 1132 amino acids and plays an important role in cell lifespan. At least, three domains can be distinguished in the structure of TERT structure. RNA-binding domain of telomerase knows as TRBA, reverse transcriptase domain and the poorly conserved C-terminal domain [62-64]. Certain TERT contain an additional N-terminal which facilitate the addition of telomere repeat by its implication in the process of primer binding $[62,65]$. Telomerase also contains the region which acts as a template for telomere synthesis [66, 67]. Telomere RNA (TER) structure 
contains certain conserve elements such as template region, the pseudoknot, the trans-activating domain and the domains required to ensure in-vivo stability, meaning that TER contains the essential elements for telomerase activity, assembly, localization and stability of RNA. Apart from the telomerase activity of telomerase, telomerase and telomerase component have an alternative functions in cell life such as telomerase nuclease activity because the length of the final products depends on the template region of telomerase RNA [68], transferase activity via stimulation of certain small molecules [69, 70], mitochondrial function activity via implication of hTERT in replication and repair of mtDNA [71], DNA damage activity [72] and regulation of gene activity [73-75]. According to the relationship between telomerase and telomere and their roles in cell function and life, dysfunction of telomere and /or telomerase can lead to dysfunction of a cell (disease).

\section{Telomere and telomerase in human diseases especially cancer}

Telomere and telomerase, via their dysfunction, are implicated in several human diseases such as chronic lung disease [76-78], chronic obstructive pulmonary disease and idiopathic pulmonary fibrosis [79-81], diabetes $[82,83]$, autoimmune disease (rheumatoid arthritis, systemic Lupus erythematosus, sclerosis) [84-88], renal failure (chronic kidney disease) [89], cardiovascular disease [90-92], Parkinson disease [93, 94], chronic infection [95, 96], obesity [97], cancer [28], etc.

As mentioned above, telomere become short after each cell division because of «end replication problem» and this telomere shortening is a natural phenomenon in cell viability and chromosome stability where the lagging strand DNA synthesis cannot be completed all the way to the very end. In this case, increasing the division of the cells leads to very short telomere which causes the DNA damage responses that trigger cellular senescence [98]. The cells in senescence phase have short telomere and are characterized by inhibition of cell proliferation. The lost of telomere quality, in that case, promotes the DNA repair system and tumor suppressor protein 53 which stimulates ${ }_{\mathrm{P}} \mathrm{Rb}$. Activation of ${ }_{\mathrm{P}}$ and ${ }_{\mathrm{PRb}}$ leads essentially to irreversible growth arrest. However, the cells which gain additional oncogenic changes such as 53 loss can pass senescence step and can continue to divide. This initiates the crisis step associated to chromosome end-toend fusion (new dysfunctional step) and increasing of the cell death [99]. However, very few human cells ( 1 in $10^{5}$ to $10^{7}$ ) can continue the division and in this case, with an acquisition of cell immortality or cancer initiation ability [100]. At this step, certain cells have very short telomere without a genomic instability which is maintained by reactivating and increasing of telomerase expression or in the rare case, by activating the telomerase-independent mechanism (ALT) [101]. Several studies demonstrated the correlation between telomere shortening and cancer risk with cancer type -dependent $[102,103]$. In the population level, it has been reported that patients with short telomere in peripheral blood cell have a high risk to develop cancer [104]. However, the shortening of telomere is supposed to protect against the malignant transformation of the cells by limiting cell proliferation. For its confirmation, It's found that peoples with short telomere length have a low risk of

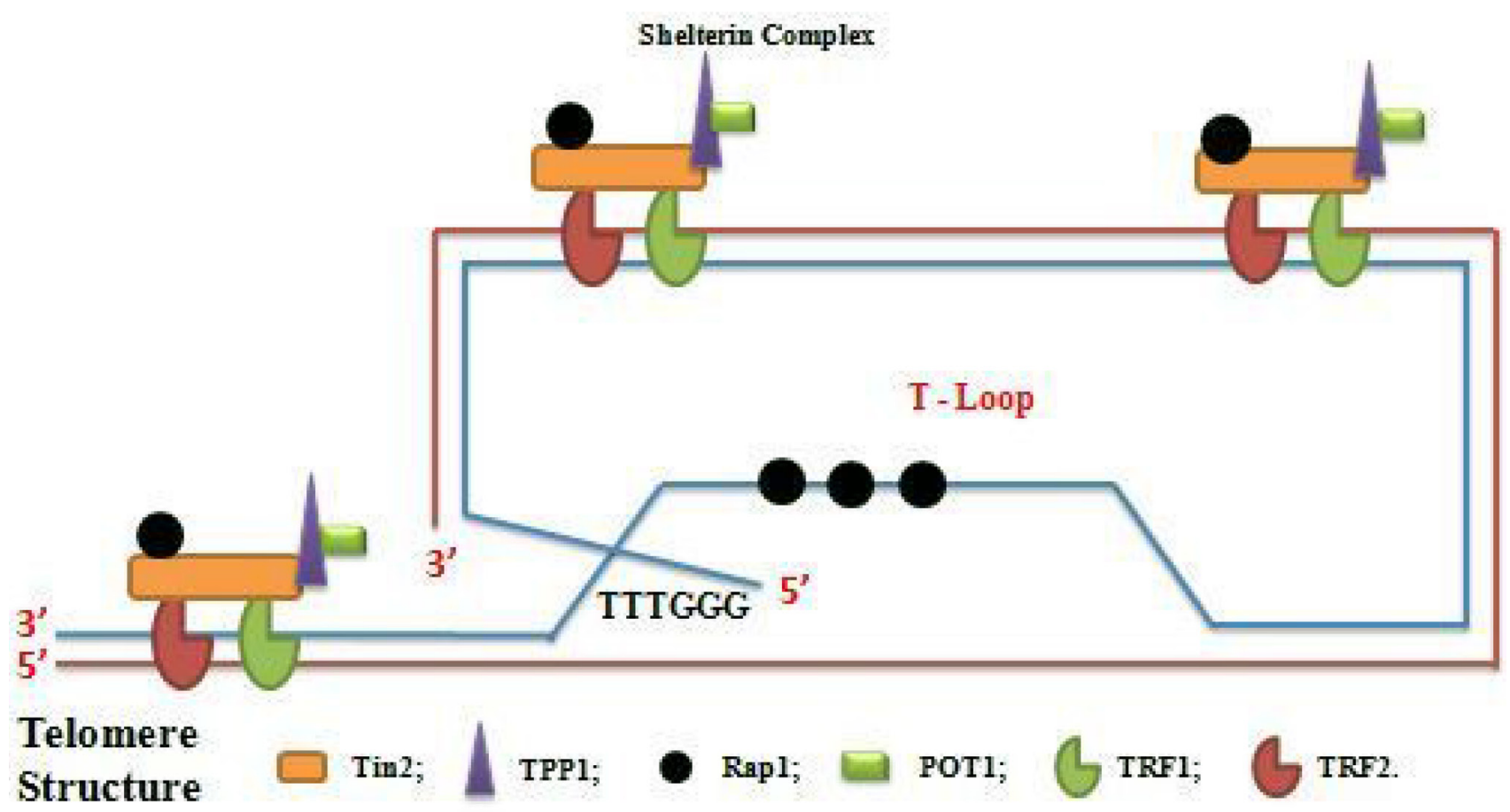

Figure 1: Schema of telomere structure with shelterin complex (Telosome) and T-loop formation. 
melanoma development than control [105] suggesting that chromosome instability is indispensable in the occurrence of cancer initiation mediated by telomere dysfunction and only telomere shortening induced chromosome instability is implicated in cancer initiation and progression [106-109]. This confirms the discover mentioning that telomerase is reactivated and overexpressed with bypass crisis step where chromosome end fusion, rearrangement of the chromosome, malignant transformation have occurred. Kim NW et al. reported that high levels of telomerase expression associated with telomere shortening is detected in most of human cancer to assume telomere elongation and maintenance whereas it is absent in most of the normal somatic cells or tissues [28]. Although telomerase has a high preference for short telomere $[110,111]$ which is implicated in cancer initiation, its expression is controversial because some cancer cell does not have a high level of telomerase expression which may be due to ALT mechanism. Because telomerase consists of catalytic subunit telomerase reverse transcriptase (TERT), Telomerase RNA component (TERC) and telomerase complex associated protein, upregulation of telomerase expression is correlated with increasing of copy number of hTERT which is strongly positive in tumor cell [112] and correlated with telomerase activity, cancer initiation and progression [113-115]. Based on the important role of telomere shortening induced genomic instability and telomerase in cancer development, they can be considered as a good target for reinforcement of strategies for improvement of cancer therapy especially cancer radiotherapy.

\section{THERAPIES-ASSOCIATED WITH TELOMERE OR TELOMERASE MODULATION AND CANCER CELLS RADIOSENSITIVITY}

\section{Telomere and telomerase as good targets for enhancement of cancer radiosensitivity}

Several studies reported the link between short telomere and radiosensitivity [116, 117]. In human, irradiation induces damage in people with short telomere than people with long telomere $[118,119]$. In cell level, Zhong YH. et al. reported that there is a negative correlation between radiosensitivity of 15 human carcinoma cell lines from different tissues and their telomere length [120]. In the same way, Cabuy E. et al. showed that high radiosensitivity human cells have short telomere than the normal cell [121]. McIlrath $J$. et al., also reported that murine lymphoma cells L5178Y-S which have $7 \mathrm{~Kb}$ is more radiosensitive than L5178Y-S having $48 \mathrm{~Kb}$ [116]. The negative correlation between radiosensitivity and telomere shortening may be caused by telomere shortening associated to chromosome aberration
$[122,125]$ and chromosome aberration is associated to radiosensitivity [124], by chromatin structure change where the access of ATM to its target chromatin is limited $[117,123,124]$. Moreover, it has been reported that late generation of $\mathrm{mTR}(-/-)$ such as $\mathrm{G} 5 \mathrm{mTR}(-/-)$ mice and Terc- -1 mice exposed to $\gamma$-Ray shown high mortality via increase rate of apoptosis and cytogenic damage $[117,124]$, suggesting that there is also a negative correlation between telomerase and cancer cells radiosensitivity. Based on those data, telomere and telomerase can be considered as good biomarkers for cancer radiosensitivity and their modulation can enhance cancer response to irradiation.

\section{Telomere dysfunction and radiosensitivity}

Several telomere or telomerase modulation approach such as Telomere Homolog Oligonucleotide, G-quadruplex Ligand, targeting of telosome or another Telomere maintenance proteins has been demonstrated to be implicated in telomere dysfunction -associated with modulation of cancer radiosensitivity.

\section{T-Oligos and G4-Ligand}

Telomere Homolog Oligonucleotide called T-Oligos and G-quadruplex Ligand or G4-Ligand are developed and used to induce telomere dysfunction mediated enhancement of cancer radiosensitivity. Telomere Homolog Oligonucleotide called T-Oligos mechanism of action is to accumulate in the nucleus and rapidly promoted DDRs at telomere-mediated by 53 , ATM, E2F1, cdk2 and ${ }_{\mathrm{P}} 95 / \mathrm{NBS} 1$ which finally leads to cell cycle arrest, senescence, apoptosis [126-130]. Because of its specific anti-cancer effect, T-Oligos is showed to highly affected viability and growth of cancer lung cell, melanoma, prostate, ovarian, breast and colorectal cancer $[129,131-134]$. T11 is one of T-oligos which consists of 11 oligonucleotides and has an anti-cancer effect in several types of cancer [135-136] in-vitro and in-vivo $[137,138]$. It enhances the anti-cancer effect of irradiation [139]. G-quadruplex or G4 is a structure which forms naturally in telomere region by folding of non-coding repeat sequence of guanine-rich DNA (Telomeric ends called G-rich ends of the chromosome). By its ligand, G4 stabilization can prevent telomere elongation which leads to telomere embrittlement [140]. G4-Ligand is G4 stabilizing ligand used as a potential treatment for cancer development and progression [141]. Several G4 ligands are developed and used as cancer therapy whereas very few are used in combination with radiotherapy. It is reported that G4-ligand binds to G4 DNA and highly sensitizes cancer cell to irradiation [142]. Pt-ctpy also is kind of G4-ligand with a good affinity for G4 DNA [143] and belongs to tolyterpyridine metal $[144,145]$. Merle $P$ et al. reported that Pt-Ctpy induced reduction of GBM and NSCLC cell proliferation in concentration- 
dependent-manner, induced the accumulation of S-phase cells, G2/M phase cell and apoptosis cells [142]. Pt-Ctpy is well tolerated without toxic effect where it's used alone and it increased irradiation effect in-vitro and in-vivo when it is used in combination and before radiotherapy. TAC is another G4 Ligand and contains $70 \%$ of TAC$\mathrm{Me} 2$ and $30 \%$ of TAC-Me3. It is reported as inhibitor of cancer cell (GBM) proliferation in a dose-dependent manner via a minimal effect on cell cycle and apoptosis after one week alone treatment. However, the therapeutic dose (5 Gy) of TAC which does not have an effect on cell cycle and apoptosis induced high sensitization of GBM cell to irradiation [146]. The pentacyclic acridine RHPS4 is also G4 Ligand implicated in telomere no protection (dysfunction) and blockage of cell proliferation [147-149]. By using the comparison between the survival curves, Berardinelli $F$. et al. reported that RHPS4 enhanced cancer cell radiosensitivity. In the same report, U251MG radioresistant cancer cells pretreated $120 \mathrm{~h}$ with $0.2 \mu \mathrm{M}$ of RHPS4 before $2 \mathrm{~Gy}$ irradiation showed $53 \%$ of reduction of survival whereas unpretreated cell showed $20 \%$ of decreasing and RHPS 4 combine with irradiation $(0.2 \mu \mathrm{M}$ of RHPS $4+3 \mathrm{~Gy})$ activate a transient $\mathrm{G} 2$ phase blockage which leads to the cell proliferation reduction at 0.61 proportion and 0.84 proportion of cell proliferation reduction for (3 Gy) [150].

\section{Telosome modulation and cancer radiosensitivity}

As telomere maintenance element, telosome (telomere sheltering complex protein) is a complex of 6 proteins (TRF1, TRF2, RAP1, TIN2, TPP1 and POT1) which modulation is one of the ways to promote telomere dysfunction associated to cancer high radiosensitivity.

Zhou YF et al. reported that POT1 which is one of telosome is implicated in the regulation of cell radiosensitivity [151]. Otherwise, the POT1 expression is in positive correlation with telomere length because patients with high level of POT1 have long telomere and were photon irradiation resistant [152]. Downregulation of POT1 by using siRNA increase human cancer cell radiosensitivity. TRF2 also is one of telosome and is implicated in the modulation of cancer radiosensitivity. It is reported that inhibition of TRF2 expression enhanced the effect of 2.5 Gy of $\gamma$-Ray irradiation by decreasing scurvies cell fraction [153] and by increasing $\gamma-\mathrm{H} 2 \mathrm{AX}$ foci leading to the reduction of telomere protection from irradiation consequence of high radiosensitivity [154]. TPP1 is one of the radioresistance proteins because it is overexpressed in the radioresistant cancer cells and its ectopic expression confers radioresistance ability to cancer cell [155]. Zhou YF et al. reported that modulation of TPP1 modulates telomere homeostasis and radioresistance of human colorectal cancer [156]. It's also reported that its suppression enhanced cancer radiosensitivity in telomerase negative cell by inducing telomere dysfunction [157].
However, the role of Rap1, TRF1 and Tin2 which are also a part of shelterin complex, is not known yet in cancer radiosensitivity. Then, it will be good to encourage more research concerning that to clearly master the role of those proteins particularly and generally, telosome in cancer response to irradiation in the relationship with telomere function.

\section{Other telomere maintenance proteins and cancer radiosensitivity}

The telomere maintenance component 1 (CTC1) is the third member of the CST (CTC1-STN1-TEN1) complex binding to telomere and assume its integrity [158]. CTC1 knock-down promotes great telomere loss $[159,160]$ and it implicated in the modulation of radiosensitivity. Zhou YH et al. demonstrated that CTC1 expression is inhibited in radiosensitive human melanoma cells compared to radioresistant cells and its total inhibition increased cell radiosensitivity by promoting telomere shortening and apoptosis [161]. Ku80 is one of the subunits of the $\mathrm{Ku} 80 / \mathrm{Ku} 70$ heterodimer which is implicated in telomere maintenance by binding to the DSB ends and by initiating its repair via DNA-PKCs recruitment $[162,163]$. It's reported that its deficiency leads to cancer cells sensitization to irradiation and Ku80 mutation also leads to telomere ends repair prevention [164] which decreased telomere length and enhanced the response of many cancer cell line to irradiation [165]. Otherwise, Zhou FX et al. reported that down-regulation of $\mathrm{Ku} 80$ by using siRNA enhanced the radiosensitivity of telomerase deficiency cell U2OS by inducing telomere shortening [166]. The high mobility group box 1 (HMGB1) is a ubiquitous chromatin-associated protein which implicated in non-homologous end-joining, mishmash repair [167] and telomere maintenance. It's implicated in cancer progression and its Knockdown in mouse embryonic fibroblast (MEFs) leads to telomere dysfunction [168]. Moreover, Zhou YF et al. reported that inhibition of HMGB1 enhanced human cell radiosensitivity via inhibition of repair kinetics of DNA damage induced by irradiation, increasing of apoptosis, decreasing of the proportion of cell in S-phase and induction of telomere shortening [169]. WRAP53 protein is implicated in telomere elongation caused by telomerase and is highly expressed in a cancer cell [170]. Depletion of WRAP53 reduced telomere length without affect telomerase activity [171-173] suggesting that it has a high relationship with telomere maintenance. WRAP53 modulation can modulate cancer radiosensitivity because of the negative correlation which exists between WRAP53 and cancer cells radiosensitivity. Decreasing of WRAP53 is associated to high radiosensitivity. $\mathrm{Xie} \mathrm{CH}$ et al., reported that in Hep2 cell, transfection of a cell by phWRAP53-siRNA for inhibition of WRAP53 expression before irradiation showed high radiosensitivity 
via telomere shortening than non-transfected cells [174]. All data mentioned above indicate that telomere play an important role in cells function and its dysfunction is lethal for cancer cells which can lead to enhancement of cancer therapy such as cancer radiotherapy. Basing on the relationship between telomere and telomerase, targeting telomerase may also be one way to promote telomere dysfunction-induced radiosensitivity.

\section{TELOMERASE MODULATION AND CANCER CELLS RADIOSENSITIVITY}

Several strategies or techniques such as oligonucleotide inhibitor, the small-molecule telomerase inhibitor, Immunotherapy approach (Vaccinotherapy), Telomerase direct or indirect gene therapy (RNA interference) and phytotherapy are developed and used in cancer therapy. Among them, few are used, as telomerase inhibitor by targeting of telomerase RNA (TR) or telomerase reverse transcriptase (TERT), in combination with irradiation to enhance cancer cells response to irradiation via telomere shortening (Telomere dysfunction).

\section{Telomerase activity Oligonucleotide inhibitor and cancer cells radiosensitivity}

Imetelestat (GRN163L) is a 13-mer oligonucleotide which reported to suppress catalytic activity of telomere by targeting the template region of hTR $[175,176]$. Its anticancer effect is reported on breast cancer [177], prostate cancer [178], glioblastoma [179], myeloma leukemia [180] and it is also showed as cancer radiosensitivity modulator. Zhigang $G$ et al. reported that imetelestat treatment before irradiation enhanced esophageal squamous cancer cells response to irradiation by inducing DNA break (apoptosis) and reducing cell proliferation in-vitro and in-vivo [181]. Similar results are discovered by Gomez-Millan $J$ et al. on breast cancer cell where treatment of MDAMB-231 cancer cell with GRN163L enhanced cancer radiosensitivity in-vitro and in-vivo [182] via telomerase activity and telomere length inhibition. Sylvain $T$ et al. also showed that imetelestat increased the response of a tumor to irradiation illustrated by tumor volume reduction and inhibition of telomerase activity [183]. ASODN is another oligonucleotide inhibitor which inhibits telomerase activity via targets of human telomerase RNA and called hTR ASODN. Zhou YF et al. reported that hTR ASODN increased esophageal squamous cancer cells sensitivity to irradiation by down-regulating telomerase activity and increased human neuroglioma cell (U251) sensitivity to irradiation by inducing DNA damage and by reducing cell proliferation [184]. In 2005, Zhonghua Yu et al. reported the similar results on nasopharyngeal carcinoma cells where cells treated with the combination of hTR ASODN and irradiation showed high sensitivity to irradiation via reduction of their proliferation and their telomere length [185].

\section{Direct or indirect gene therapy targeting telomerase and cancer radiotherapy}

Direct gene therapy of telomerase means the use of RNA interference (siRNA, shRNA, miRN...; etc) to post-transcriptionally silence telomerase gene expression which leads to telomerase mRNA reduction. This kind of telomerase reduction can lead to telomere shortening and can be implicated in radiosensitivity modulation because certain TERT or TERT promoters' mutations are associated to telomere length and predict poor survival and radioresistance [186]. Mice deficient in the RNA component of Telomerase is high radiosensitive [117, 124] and HCT116 cells with hTERT allele disruption (hTERT +/-) called haplo insufficient had a reduction of telomerase activity, telomere length and are more radiosensitive [187]. The similar results were reported by several discovers where direct inhibition of telomerase expression by transfecting cancer cell with RNAi and with shRNA before irradiation enhanced the effect of irradiation via reduction of telomerase activity and/or telomere length [188-192].

Many researches are carried out concerning the indirect target of telomerase which is the target of a protein implicated in telomerase function. Survivin is a member of the inhibitor of apoptosis (IAP) protein family and is highly expressed in most of the cancer cells whereas it is undetectable in normal cells [193, 194]. Zhang $H Z$ et al. reported that the use of siRNA to inhibit telomerase activity in control of surviving promoter enhanced radiotherapy effect in Hela cell in-vitro and in-vivo [195]. Ubiquitin-Conjugating Enzyme called $\mathrm{UBE}_{2} \mathrm{D}_{3}$ or $\mathrm{E}_{2} \mathrm{D}_{3}$ is a key component in ubiquitin-proteasome system and is reported to lowly express in many cancer cell line [196]. Zhou YF et al. demonstrated that UBE2D3 is negatively correlated to radioresistance [197-200] and its inhibition decreased radiosensitivity by increasing hTERT expression and telomerase activity in MCF-7 cell [199]. The author also reported that UBE2D3 overexpression enhances radiosensitivity by reducing telomerase activity and telomere length in esophageal cancer cell in-vitro and in-vivo [200]. Tankyrase 1 (TNKS1) is a protein required for telomerase activity [201-203]. Indirect telomerase inhibition by using siRNA TNKS1 against TNKS1 leads to telomere uncapping and increasing of cancer cell ionizing irradiation sensitivity [204]. The latent membrane protein (LMP1) encodes by Epstein-Bar Virus (EBV) is suggested to be one of the major oncogenic factors in nasopharyngeal cancer cell line and is implicated in hTERT activation. EBV-LMP1 DNAzyme $\left(\mathrm{D}_{2} \mathrm{~L}\right)$ is a DNA enzyme which binding to their target RNA via Wastor-Crick base-pairing and cleaves the mRNA of $\mathrm{LMP}_{1}$ [205]. It is reported that activation of hTERT is mediated by LMP1 and targeting 
LMP1 by using D2L leads to increase of radiosensitivity via inhibition of hTERT expression and telomerase activity [206].

\section{Phytotherapy associated with telomerase targeting and cancer radiosensitivity}

Phytotherapy is the use of the vegetable drug or vegetable extraction to treat diseases including cancer [207]. Many of them showed an anti-cancer effect by targeting telomerase expression or telomerase activity while few of them are used in combination with radiotherapy for radiotherapy effect enhancement. Panax ginseng is one of the most common herbals in medicine and ginseng saponins (ginsenosides) are its major active components. As an anti-cancer product, ginseng saponing is reported to have an anti-tumor effect by downregulating telomerase activity [208, 209]. It is also reported that panax ginseng (ginseng sponing) modulated radiosensitivity of cancer cell. You JS. et al. reported

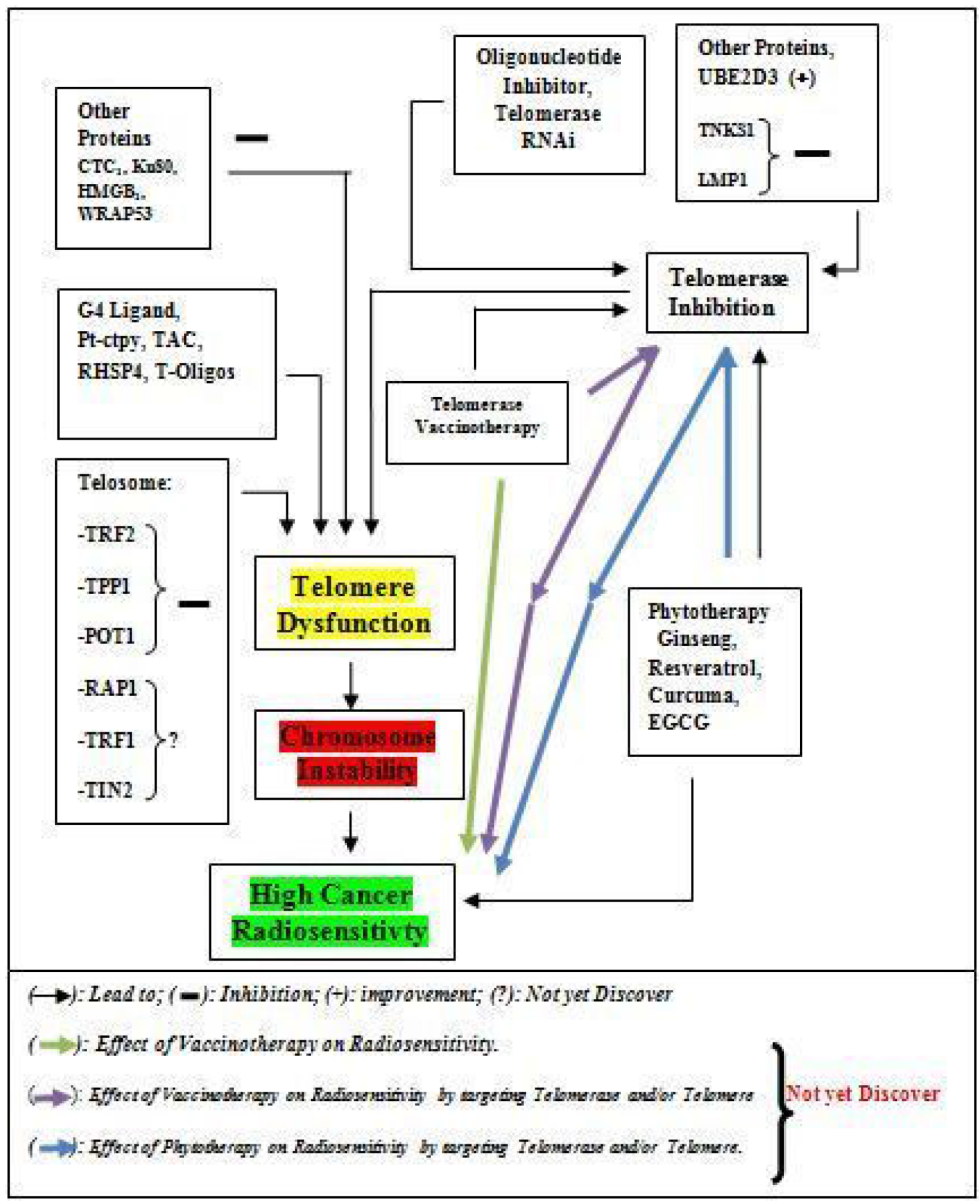

Figure 2: Schematic diagram of link between therapies associated with telomere or telomerase modulation and Cancer Radiosensitivity. 
that the use of ginseng in combination with radiotherapy more reduced the survival rate of tumor cell $(66.7 \%)$ vs (75.3\%) and $(76.1 \%)$ for ginseng and irradiation alone treatment respectively. Suggesting that the synergic use of ginseng and radiotherapy may increase cancer cells radiosensitivity and may decrease irradiation side effects [210]. Resveratrol is a major component of polyphenol from grapes and it was used for many disease treatments including cancer [211-215]. It is also reported that its relative high concentration substantially inhibited cancer proliferation and telomerase activity in human colorectal cancer and in breast cancer cell line [214, 216]. Resveratrol enhanced EOL1 cancer cell radiosensitivity by inducing apoptosis [217], NSCLC cancer cell radiosensitivity by increasing ROS generation and DNA DSBs [218] and MCF-7 cancer cell radiosensitivity by inducing cell cytotoxicity and activating of different pathways of cellular death [219]. Curcuma is polyphenol contains in Curcuma Longa and its anti-proliferative effect was reported in many types of cancer cell line such as head and neck squamous cancer cell, breast cancer, prostate cancer, lung cancer, pancreas cancer [220-226]. Anticancer effect of Curcuma is associated with apoptosis induction and reduction of telomerase expression or activity in several cancer cell lines [227-230]. It is reported to enhance cancer radiosensitivity [217] via the different mechanisms such as suppression of NF-kb activity [231]. Epigallocatechin-3-gallate (EGCG) is a major polyphenol (more than $50 \%$ of total polyphenol) contains in green tea [232]. As a possessor of specific anti-cancer ability [233, 234], EGCG showed its anti-proliferative effect via the different mechanisms like induction of apoptosis, inhibition of cell migration, inhibition of telomerase expression or telomerase activity and telomere length [235-240]. EGCG used in combination with X-irradiation resulted in enhancement of cancerous cell line response to irradiation [217, 241].

However, the mechanisms of synergic effect of phytotherapy products mentioned above (ginseng, Curcuma, resveratrol, EGCG) combined with irradiation treatment does not include telomere or telomerase targeting. It will be good to encourage more research concerning that to know if targeting telomere or telomerase is included in the mechanism of their synergic effect on cancer cell radiosensitivity.

\section{ADVANTAGES OF THE USE OF THE COMBINATION OF THERAPIES TARGETING TELOMERE OR TELOMERASE AND CANCER RADIOTHERAPY}

Radiotherapy for curative treatment has an important part in cancer treatment with many advantages and disadvantages. The main disadvantages of radiotherapy are the damage of normal tissues or cells which depend on the volume of tissue, the total dose of radiation, the dose per fraction of radiation, irradiation delivery method, factor and comorbidities of the patients [14,242]. The damage of normal tissues by radiotherapy can lead to cardiovascular diseases, a pulmonary complication, infertility, endocrinopathy abnormality and second malignancy [243, 244], dermatitis [245], and gastrointestinal diseases [246], which are known as side effects of the post-cancer radiotherapy, are a major health and socio-economic problems. Combination of other therapy which modulates telomere and/or telomerase associated with a reduction of cancer proliferation and radiotherapy (Figure 2) is one of the strategies for reducing total dose of irradiation which may reduce side of effect induce by high total irradiation or per fraction irradiation dose. Based on these advantages, it will be good to complete the list of targeting telomere or telomerase mediated high radiosensitivity treatment such as vaccine-therapy (immunotherapy) which can be used in combination with irradiation treatment to improve irradiation effect. In our case, telomerase vaccine-therapy leads to high expression of telomerase in cancer treatment in-vitro and in-vivo manner and as a tumor neo-antigen to stimulate the cancer cells deaths since it is reported that TERT is a tumor-associated antigen (TAA) which caused antitumor $\mathrm{CD} 8+$ cytotoxic lymphocyte (CTL) response in several types of tumor [247]. Several telomerase vaccines are developed and used in the treatment of cancer in fundamental and clinical research [248] where they showed a high anti-tumor effect by activating an immune system against telomerase for its destruction [249]. For this, more research should be encouraged to explore more on the combination of telomerase vaccine and irradiation in future and application of that kind of combination for cancer treatment could enhance radiotherapy effect and reduce side of effect post-cancer radiotherapy.

\section{CONCLUSIONS}

Radiotherapy is one among the of cancer treatment and plays an important role in treating cancer. As other cancer treatments, radiotherapy efficacy has also certain limitation such as cancer radiotherapy resistance and side of effect post-cancer radiotherapy. Telomere and telomerase are cancer markers and are implicated in cancer development, cancer treatment and limitation of cancer treatment effectiveness such as cancer radiotherapy limitation especially cancer radio-resistance. Combination of two treatments by modulating telomere or telomerase before radiotherapy treatment improves cancer radiosensitivity if only the modulation of telomere or telomerase is associated with chromosome instability. Meaning that chromosome instability is the key factor of telomere or telomerase modulation mediated high cancer radiosensitivity. However, several researches need to be done concerning the reinforcement of cancer radio- 
gene-therapy used before and certain kind of cancer treatment such as vaccine-therapy and phytotherapy need to be used in combination with radiotherapy to expand the group of therapies mediated telomere or telomerase targeting (chromosome instability) which could be used in combination with radiotherapy for reducing its effectiveness limitation especially, via the enhancement of cancer radiosensitivity.

\section{Author contributions}

GA was in charge of conceiving, designing and drafting of the manuscript. YX was in charge of its reading. GA was in charge of its reading and correction. FZ and YZ supervised the manuscript writing.

\section{ACKNOWLEDGMENTS}

We thank China Scholarship Council for supporting $\mathrm{PhD}$ study of GA and this work.

\section{CONFLICTS OF INTEREST}

No competing interests regarding this review.

\section{FUNDING}

China Scholarsuip Council (Serial number: 351569).

\section{REFERENCES}

1. Wang H, Naghavi M, Allen C, Barber RM, Bhutta ZA, Carter A, Casey DC, Charlson FJ, Chen AZ, Coates MM, Coggeshall M, Dandona L, Dicker DJ, et al, and GBD 2015 Mortality and Causes of Death Collaborators. Global, regional, and national life expectancy, all-cause mortality, and cause-specific mortality for 249 causes of death, 1980-2015: a systematic analysis for the Global Burden of Disease Study 2015. Lancet. 2016; 388:1459-544.

2. Clifton K, Gutierrez-Barrera A, Ma J, Bassett R Jr, Litton J, Kuerer H, Moulder S, Albarracin C, Hortobagyi G, Arun B. Adjuvant versus neoadjuvant chemotherapy in triplenegative breast cancer patients with BRCA mutations. Breast Cancer Res Treat. 2018; 170:101-09.

3. Ochoa CE, Joseph RW. Nivolumab in Renal Cell Carcinoma: Current Trends and Future Perspectives. J Kidney Cancer VHL. 2018; 5:15-18.

4. Liu F, Xu K, Yang H, Li Y, Liu J, Wang J, Guan Z. A novel approach to glioma therapy using an oncolytic adenovirus with two specific promoters. Oncol Lett. 2018; 15:3362-68.

5. Sakurai Y, Kajimoto K, Harashima H. Anti-angiogenic nanotherapy via active targeting systems to tumors and adipose tissue vasculature. Biomater Sci. 2015; 3:1253-65.
6. Bykov IM, Izhnina EV, Kochurova EV, Lapina NV. Radiation-associated changes in salivation of patients with cancer of maxillofacial region. [Article in Russian] Stomatologiia (Mosk). 2018; 97:67-70.

7. Liu L, Zuo J, Wang G. Epigallocatechin-3-gallate suppresses cell proliferation and promotes apoptosis in Ec9706 and Eca109 esophageal carcinoma cells. Oncol Lett. 2017; 14:4391-95.

8. Delaney G, Jacob S, Featherstone C, Barton M. The role of radiotherapy in cancer treatment: estimating optimal utilization from a review of evidence-based clinical guidelines. Cancer. 2005; 104:1129-37.

9. Delaney G, Jacob S, Barton M. Estimating the optimal external-beam radiotherapy utilization rate for genitourinary malignancies. Cancer. 2005; 103:462-73.

10. Pedroza-Torres A, Campos-Parra AD, Millan-Catalan O, Loissell-Baltazar YA, Zamudio-Meza H, Cantu de Leon D, Montalvo-Esquivel G, Isla-Ortiz D, Herrera LA, AngelesZaragoza O, Robelo-Romero G, Herrera-Gomez A, PerezPlasencia C. MicroRNA-125 modulates radioresistance through targeting p21 in cervical cancer. Oncol Rep. 2018; 39:1532-40.

11. Cox JD, Stetz J, Pajak TF. Toxicity criteria of the Radiation Therapy Oncology Group (RTOG) and the European Organization for Research and Treatment of Cancer (EORTC). Int J Radiat Oncol Biol Phys. 1995; 31:1341-46.

12. Mirjolet C, Boidot R, Saliques S, Ghiringhelli F, Maingon P, Crehange G. The role of telomeres in predicting individual radiosensitivity of patients with cancer in the era of personalized radiotherapy. Cancer Treat Rev. 2015; 41:354-60.

13. Uziel O, Lahav M. Conventional anticancer therapeutics and telomere maintenance mechanisms. Curr Pharm Des. 2014; 20:6452-65.

14. Ganeshan DM, Salem U, Viswanathan C, Balachandran A, Garg N, Silverman P, Bhosale P. Complications of oncologic therapy in the abdomen and pelvis: a review. Abdom Imaging. 2013; 38:1-21.

15. McClintock B. The stability of broken ends of chromosomes in Zea mays. Genetics. 1941; 26:234-82.

16. Muller HJ. The remaking of chromosomes. Collect. NetWoods Hole. 1938; 13:181-98.

17. Moyzis RK, Buckingham JM, Cram LS, Dani M, Deaven LL, Jones MD, Meyne J, Ratliff RL, Wu JR. A highly conserved repetitive DNA sequence, (TTAGGG)n, present at the telomeres of human chromosomes. Proc Natl Acad Sci USA. 1988; 85:6622-26.

18. Meyne J, Ratliff RL, Moyzis RK. Conservation of the human telomere sequence (TTAGGG)n among vertebrates. Proc Natl Acad Sci USA. 1989; 86:7049-53.

19. Makarov VL, Hirose Y, Langmore JP. Long G tails at both ends of human chromosomes suggest a $\mathrm{C}$ strand degradation mechanism for telomere shortening. Cell. 1997; 88:657-66. 
20. Wright WE, Tesmer VM, Huffman KE, Levene SD, Shay JW. Normal human chromosomes have long G-rich telomeric overhangs at one end. Genes Dev. 1997; 11:2801-09.

21. Allsopp RC, Vaziri H, Patterson C, Goldstein S, Younglai EV, Futcher AB, Greider CW, Harley CB. Telomere length predicts replicative capacity of human fibroblasts. Proc Natl Acad Sci USA. 1992; 89:10114-18.

22. Vaziri H, Dragowska W, Allsopp RC, Thomas TE, Harley CB, Lansdorp PM. Evidence for a mitotic clock in human hematopoietic stem cells: loss of telomeric DNA with age. Proc Natl Acad Sci USA. 1994; 91:9857-60.

23. de Lange T. Shelterin: the protein complex that shapes and safeguards human telomeres. Genes Dev. 2005; 19:2100-10.

24. Ozturk MB, Li Y, Tergaonkar V. Current Insights to Regulation and Role of Telomerase in Human Diseases. Antioxidants. 2017; 6:E17.

25. Venteicher AS, Meng Z, Mason PJ, Veenstra TD, Artandi SE. Identification of ATPases pontin and reptin as telomerase components essential for holoenzyme assembly. Cell. 2008; 132:945-57.

26. Low KC, Tergaonkar V. Telomerase: central regulator of all of the hallmarks of cancer. Trends Biochem Sci. 2013; 38:426-34.

27. Venteicher AS, Abreu EB, Meng Z, McCann KE, Terns RM, Veenstra TD, Terns MP, Artandi SE. A human telomerase holoenzyme protein required for Cajal body localization and telomere synthesis. Science. 2009; 323:644-48.

28. Kim NW, Piatyszek MA, Prowse KR, Harley CB, West MD, Ho PL, Coviello GM, Wright WE, Weinrich SL, Shay JW. Specific association of human telomerase activity with immortal cells and cancer. Science. 1994; 266:2011-15.

29. Shay JW, Bacchetti S. A survey of telomerase activity in human cancer. Eur J Cancer. 1997; 33:787-91.

30. Armanios M, Greider CW. Telomerase and cancer stem cells. Cold Spring Harb Symp Quant Biol. 2005; 70:205-08.

31. Marusyk A, Polyak K. Tumor heterogeneity: causes and consequences. Biochim Biophys Acta. 2010; 1805:105-17.

32. Flores I, Canela A, Vera E, Tejera A, Cotsarelis G, Blasco MA. The longest telomeres: a general signature of adult stem cell compartments. Genes Dev. 2008; 22:654-67.

33. Lopez-Otin C, Blasco MA, Partridge L, Serrano M, Kroemer G. The hallmarks of aging. Cell. 2013; 153:1194-217.

34. Pardue ML, DeBaryshe G. Telomeres in Cell Function: Cancer and Ageing. Wiley Online Library. 2009 Sept 15. https://doi.org/10.1002/9780470015902.a0001168.pub2.

35. Decottignies A. [The telomere position effect: silence in the back row!]. Med Sci (Paris). 2014; 30:173-78.

36. Robin JD, Ludlow AT, Batten K, Magdinier F, Stadler G, Wagner KR, Shay JW, Wright WE. Telomere position effect: regulation of gene expression with progressive telomere shortening over long distances. Genes Dev. 2014; 28:2464-76.

37. Kim W, Ludlow AT, Min J, Robin JD, Stadler G, Mender I, Lai TP, Zhang N, Wright WE, Shay JW. Regulation of the human telomerase gene TERT by telomere position effectover long distances (TPE-OLD): implications for aging and cancer. PLoS Biol. 2016; 14:e2000016.

38. Donate LE, Blasco MA. Telomeres in cancer and ageing. Philos Trans R Soc Lond B Biol Sci. 2011; 366:76-84.

39. Bodnar AG, Ouellette M, Frolkis M, Holt SE, Chiu CP, Morin GB, Harley CB, Shay JW, Lichtsteiner S, Wright WE. Extension of life-span by introduction of telomerase into normal human cells. Science. 1998; 279:349-52.

40. Greider CW, Blackburn EH. A telomeric sequence in the RNA of Tetrahymena telomerase required for telomere repeat synthesis. Nature. 1989; 337:331-37.

41. Olovnikov AM. A theory of marginotomy. The incomplete copying of template margin in enzymic synthesis of polynucleotides and biological significance of the phenomenon. J Theor Biol. 1973; 41:181-90.

42. Harley CB, Futcher AB, Greider CW. Telomeres shorten during ageing of human fibroblasts. Nature. 1990; 345:458-60.

43. Counter CM, Avilion AA, LeFeuvre CE, Stewart NG, Greider CW, Harley CB, Bacchetti S. Telomere shortening associated with chromosome instability is arrested in immortal cells which express telomerase activity. EMBO J. 1992; 11:1921-29.

44. Shay JW, Wright WE. Hayflick, his limit, and cellular ageing. Nat Rev Mol Cell Biol. 2000; 1:72-76.

45. Hayflick L, Moorhead PS. The serial cultivation of human diploid cell strains. Exp Cell Res. 1961; 25:585-621.

46. Shay JW. Role of Telomeres and Telomerase in Aging and Cancer. Cancer Discov. 2016; 6:584-93.

47. Greider CW, Blackburn EH. Identification of a specific telomere terminal transferase activity in Tetrahymena extracts. Cell. 1985; 43:405-13.

48. de Lange T. How telomeres solve the end-protection problem. Science. 2009; 326:948-52.

49. Vulliamy TJ, Marrone A, Knight SW, Walne A, Mason PJ, Dokal I. Mutations in dyskeratosis congenita: their impact on telomere length and the diversity of clinical presentation. Blood. 2006; 107:2680-85.

50. Mitchell JR, Wood E, Collins K. A telomerase component is defective in the human disease dyskeratosis congenita. Nature. 1999; 402:551-55.

51. Vulliamy T, Marrone A, Goldman F, Dearlove A, Bessler M, Mason PJ, Dokal I. The RNA component of telomerase is mutated in autosomal dominant dyskeratosis congenita. Nature. 2001; 413:432-35.

52. Walne AJ, Vulliamy T, Marrone A, Beswick R, Kirwan M, Masunari Y, Al-Qurashi FH, Aljurf M, Dokal I. Genetic heterogeneity in autosomal recessive dyskeratosis congenita 
with one subtype due to mutations in the telomeraseassociated protein NOP10. Hum Mol Genet. 2007; 16:1619-29.

53. MacKenzie KL, Franco S, May C, Sadelain M, Moore MA. Mass cultured human fibroblasts overexpressing hTERT encounter a growth crisis following an extended period of proliferation. Exp Cell Res. 2000; 259:336-50.

54. Greider CW, Blackburn EH. The telomere terminal transferase of Tetrahymena is a ribonucleoprotein enzyme with two kinds of primer specificity. Cell. 1987; 51:887-98.

55. Blackburn EH. The end of the (DNA) line. Nat Struct Biol. 2000; 7:847-50.

56. Shcherbakova DM, Zvereva ME, Shpanchenko OV, Dontsova OA. [Telomerase: structure and properties of the enzyme, characteristics of the yeast telomerase]. Mol Biol (Mosk). 2006; 40:580-94.

57. Morin GB. The human telomere terminal transferase enzyme is a ribonucleoprotein that synthesizes TTAGGG repeats. Cell. 1989; 59:521-29.

58. Podlevsky JD, Chen JJ. It all comes together at the ends: telomerase structure, function, and biogenesis. Mutat Res. 2012; 730:3-11.

59. Chen JL, Greider CW. Determinants in mammalian telomerase RNA that mediate enzyme processivity and cross-species incompatibility. EMBO J. 2003; 22:304-14.

60. Smekalova EM, Shubernetskaya OS, Zvereva MI, Gromenko EV, Rubtsova MP, Dontsova OA. Telomerase RNA biosynthesis and processing. Biochemistry (Mosc). 2012; 77:1120-28.

61. Blackburn EH. Switching and signaling at the telomere. Cell. 2001; 106:661-73.

62. Azzalin CM, Reichenbach P, Khoriauli L, Giulotto E, Lingner J. Telomeric repeat containing RNA and RNA surveillance factors at mammalian chromosome ends. Science. 2007; 318:798-801.

63. Ganot P, Caizergues-Ferrer M, Kiss T. The family of box ACA small nucleolar RNAs is defined by an evolutionarily conserved secondary structure and ubiquitous sequence elements essential for RNA accumulation. Genes Dev. 1997; 11:941-56.

64. Jacobs SA, Podell ER, Cech TR. Crystal structure of the essential N-terminal domain of telomerase reverse transcriptase. Nat Struct Mol Biol. 2006; 13:218-25.

65. Arkhipova IR, Pyatkov KI, Meselson M, Evgen'ev MB. Retroelements containing introns in diverse invertebrate taxa. Nat Genet. 2003; 33:123-24.

66. Sperger JM, Cech TR. A stem-loop of Tetrahymena telomerase RNA distant from the template potentiates RNA folding and telomerase activity. Biochemistry. 2001; 40:7005-16.

67. Antal M, Boros E, Solymosy F, Kiss T. Analysis of the structure of human telomerase RNA in vivo. Nucleic Acids Res. 2002; 30:912-20.
68. Collins K, Greider CW. Tetrahymena telomerase catalyzes nucleolytic cleavage and nonprocessive elongation. Genes Dev. 1993; 7:1364-76.

69. Lue NF, Bosoy D, Moriarty TJ, Autexier C, Altman B, Leng $\mathrm{S}$. Telomerase can act as a template- and RNA-independent terminal transferase. Proc Natl Acad Sci USA. 2005; 102:9778-83.

70. Smekalova EM, Petrova OA, Zvereva MI, Dontsova OA. Hansenula Polymorpha TERT: A Telomerase Catalytic Subunit Isolated in Recombinant Form with Limited Reverse Transcriptase Activity. Acta Naturae. 2012; 4:70-73.

71. Sharma NK, Reyes A, Green P, Caron MJ, Bonini MG, Gordon DM, Holt IJ, Santos JH. Human telomerase acts as a hTR-independent reverse transcriptase in mitochondria. Nucleic Acids Res. 2012; 40:712-25.

72. Mahalingam D, Tay LL, Tan WH, Chai JH, Wang X. Mutant telomerase RNAs induce DNA damage and apoptosis via the TRF2-ATM pathway in telomerase-overexpressing primary fibroblasts. FEBS J. 2011; 278:3724-38.

73. Ginsberg D. E2F1 pathways to apoptosis. FEBS Lett. 2002; 529:122-25.

74. Lazzerini Denchi E, Helin K. E2F1 is crucial for E2Fdependent apoptosis. EMBO Rep. 2005; 6:661-68.

75. Perrault SD, Hornsby PJ, Betts DH. Global gene expression response to telomerase in bovine adrenocortical cells. Biochem Biophys Res Commun. 2005; 335:925-36.

76. Gansner JM, Rosas IO. Telomeres in lung disease. Trans1 Res. 2013; 162:343-52.

77. Albrecht E, Sillanpaa E, Karrasch S, Alves AC, Codd V, Hovatta I, Buxton JL, Nelson CP, Broer L, Hagg S, Mangino M, Willemsen G, Surakka I, et al. Telomere length in circulating leukocytes is associated with lung function and disease. Eur Respir J. 2014; 43:983-92.

78. Adnot S, Amsellem V, Boyer L, Marcos E, Saker M, Houssaini A, Kebe K, Dagouassat M, Lipskaia L, Boczkowski J. Telomere dysfunction and cell senescence in chronic lung diseases: therapeutic potential. Pharmacol Ther. 2015; 153:125-34.

79. Povedano JM, Martinez P, Flores JM, Mulero F, Blasco MA. Mice with pulmonary fibrosis driven by telomere dysfunction. Cell Reports. 2015; 12:286-99.

80. Le Saux CJ, Davy P, Brampton C, Ahuja SS, Fauce S, Shivshankar P, Nguyen H, Ramaseshan M, Tressler R, Pirot Z, Harley CB, Allsopp R. A novel telomerase activator suppresses lung damage in a murine model of idiopathic pulmonary fibrosis. PLoS One. 2013; 8:e58423.

81. Chen R, Zhang K, Chen H, Zhao X, Wang J, Li L, Cong Y, Ju Z, Xu D, Williams BR, Jia J, Liu JP. Telomerase deficiency causes alveolar stem cell senescence-associated low-grade inflammation in lungs. J. Biol. Chem. J Biol Chem. 2015; 290:30813-29. 
82. Liew CW, Holman A, Kulkarni RN. The roles of telomeres and telomerase in beta-cell regeneration. Diabetes Obes Metab. 2009; 11:21-29.

83. Qi Nan W, Ling Z, Bing C. The influence of the telomeretelomerase system on diabetes mellitus and its vascular complications. Expert Opin Ther Targets. 2015; 19:849-64.

84. Steer SE, Williams FM, Kato B, Gardner JP, Norman PJ, Hall MA, Kimura M, Vaughan R, Aviv A, Spector TD. Reduced telomere length in rheumatoid arthritis is independent of disease activity and duration. Ann Rheum Dis. 2007; 66:476-80.

85. Fujii H, Shao L, Colmegna I, Goronzy JJ, Weyand CM. Telomerase insufficiency in rheumatoid arthritis. Proc Natl Acad Sci USA. 2009; 106:4360-65.

86. Hoffecker BM, Raffield LM, Kamen DL, Nowling TK. Systemic lupus erythematosus and vitamin D deficiency are associated with shorter telomere length among African Americans: a case-control study. PLoS One. 2013; 8:e63725.

87. Kurosaka D, Yasuda J, Yoshida K, Yoneda A, Yasuda C, Kingetsu I, Toyokawa Y, Yokoyama T, Saito S, Yamada A. Abnormal telomerase activity and telomere length in $\mathrm{T}$ and B cells from patients with systemic lupus erythematosus. J Rheumatol. 2006; 33:1102-07.

88. Guan JZ, Guan WP, Maeda T, Guoqing X, GuangZhi W, Makino N. Patients with multiple sclerosis show increased oxidative stress markers and somatic telomere length shortening. Mol Cell Biochem. 2015; 400:183-87.

89. Wills LP, Schnellmann RG. Telomeres and telomerase in renal health. J Am Soc Nephrol. 2011; 22:39-41.

90. Fuster JJ, Andres V. Telomere biology and cardiovascular disease. Circ Res. 2006; 99:1167-80.

91. Bekaert S, De Meyer T, Rietzschel ER, De Buyzere ML, De Bacquer D, Langlois M, Segers P, Cooman L, Van Damme P, Cassiman P, Van Criekinge W, Verdonck P, De Backer GG, et al, and Asklepios investigators. Telomere length and cardiovascular risk factors in a middle-aged population free of overt cardiovascular disease. Aging Cell. 2007; 6:639-47.

92. Gizard F, Heywood EB, Findeisen HM, Zhao Y, Jones KL, Cudejko C, Post GR, Staels B, Bruemmer D. Telomerase activation in atherosclerosis and induction of telomerase reverse transcriptase expression by inflammatory stimuli in macrophages. Arterioscler Thromb Vasc Biol. 2011; $31: 245-52$.

93. Forero DA, Gonzalez-Giraldo Y, Lopez-Quintero C, Castro-Vega LJ, Barreto GE, Perry G. Telomere length in Parkinson's disease: A meta-analysis. Exp Gerontol. 2016; 75:53-55.

94. Schurks M, Buring J, Dushkes R, Gaziano JM, Zee RY, Kurth T. Telomere length and Parkinson's disease in men: a nested case-control study. Eur J Neurol. 2014; 21:93-99.

95. Williams K, Seiss K, Beamon J, Pereyra F, Rosenberg ES, Walker BD, Yu XG, Lichterfeld M. Epigenetic regulation of telomerase expression in HIV-1-specific CD8+ T cells. AIDS. 2010; 24:1964-66.

96. Cote HC, Soudeyns H, Thorne A, Alimenti A, Lamarre V, Maan EJ, Sattha B, Singer J, Lapointe N, Money DM, Forbes J, Wong J, Bitnun A, et al, and CIHR Emerging Team in HIV therapy, aging (CARMA). Leukocyte telomere length in HIV-infected and HIV-exposed uninfected children: shorter telomeres with uncontrolled HIV viremia. PLoS One. 2012; 7:e39266.

97. Carulli L, Anzivino C, Baldelli E, Zenobii MF, Rocchi $\mathrm{MB}$, Bertolotti M. Telomere length elongation after weight loss intervention in obese adults. Mol Genet Metab. 2016; 118:138-42.

98. Bourgeron $\mathrm{T}, \mathrm{Xu} \mathrm{Z}$, Doumic M, Teixeira MT. The asymmetry of telomere replication contributes to replicative senescence heterogeneity. Sci Rep. 2015; 5:15326.

99. Hayashi MT, Cesare AJ, Rivera T, Karlseder J. Cell death during crisis is mediated by mitotic telomere deprotection. Nature. 2015; 522:492-96.

100. Castro-Vega LJ, Jouravleva K, Ortiz-Montero P, Liu WY, Galeano JL, Romero M, Popova T, Bacchetti S, Vernot JP, Londono-Vallejo A. The senescent microenvironment promotes the emergence of heterogeneous cancer stem-like cells. Carcinogenesis. 2015; 36:1180-92.

101. Shay JW, Wright WE. Role of telomeres and telomerase in cancer. Semin Cancer Biol. 2011; 21:349-53.

102. Wentzensen IM, Mirabello L, Pfeiffer RM, Savage SA. The association of telomere length and cancer: a meta-analysis. Cancer Epidemiol Biomarkers Prev. 2011; 20:1238-50.

103. Ma H, Zhou Z, Wei S, Liu Z, Pooley KA, Dunning AM, Svenson U, Roos G, Hosgood HD 3rd, Shen M, Wei Q. Shortened telomere length is associated with increased risk of cancer: a meta-analysis. PLoS One. 2011; 6:e20466.

104. Broberg K, Bjork J, Paulsson K, Hoglund M, Albin M. Constitutional short telomeres are strong genetic susceptibility markers for bladder cancer. Carcinogenesis. 2005; 26:1263-71.

105. Nan H, Du M, De Vivo I, Manson JE, Liu S, McTiernan A, Curb JD, Lessin LS, Bonner MR, Guo Q, Qureshi AA, Hunter DJ, Han J. Shorter telomeres associate with a reduced risk of melanoma development. Cancer Res. 2011; 71:6758-63.

106. Artandi SE, Chang S, Lee SL, Alson S, Gottlieb GJ, Chin L, DePinho RA. Telomere dysfunction promotes nonreciprocal translocations and epithelial cancers in mice. Nature. 2000; 406:641-45.

107. Blasco MA, Lee HW, Hande MP, Samper E, Lansdorp PM, DePinho RA, Greider CW. Telomere shortening and tumor formation by mouse cells lacking telomerase RNA. Cell. 1997; 91:25-34.

108. Engelhardt M, Drullinsky P, Guillem J, Moore MA. Telomerase and telomere length in the development and progression of premalignant lesions to colorectal cancer. Clin Cancer Res. 1997; 3:1931-41. 
109. Maser RS, DePinho RA. Connecting chromosomes, crisis, and cancer. Science. 2002; 297:565-69.

110. Teixeira MT, Arneric M, Sperisen P, Lingner J. Telomere length homeostasis is achieved via a switch between telomerase- extendible and -nonextendible states. Cell. 2004; 117:323-35.

111. Bianchi A, Shore D. Increased association of telomerase with short telomeres in yeast. Genes Dev. 2007; 21:1726-30.

112. Cong YS, Wright WE, Shay JW. Human telomerase and its regulation. Microbiol Mol Biol Rev. 2002; 66:407-25.

113. Fuxe J, Akusjarvi G, Goike HM, Roos G, Collins VP, Pettersson RF. Adenovirus-mediated overexpression of p15INK4B inhibits human glioma cell growth, induces replicative senescence, and inhibits telomerase activity similarly to p16INK4A. Cell Growth Differ. 2000; 11:373-84.

114. Henderson YC, Breau RL, Liu TJ, Clayman GL. Telomerase activity in head and neck tumors after introduction of wild-type p53, p21, p16, and E2F-1 genes by means of recombinant adenovirus. Head Neck. 2000; 22:347-54.

115. Xu D, Erickson S, Szeps M, Gruber A, Sangfelt O, Einhorn S, Pisa P, Grander D. Interferon alpha down-regulates telomerase reverse transcriptase and telomerase activity in human malignant and nonmalignant hematopoietic cells. Blood. 2000; 96:4313-18.

116. McIlrath J, Bouffler SD, Samper E, Cuthbert A, Wojcik A, Szumiel I, Bryant PE, Riches AC, Thompson A, Blasco MA, Newbold RF, Slijepcevic P. Telomere length abnormalities in mammalian radiosensitive cells. Cancer Res. 2001; 61:912-15.

117. Wong KK, Chang S, Weiler SR, Ganesan S, Chaudhuri J, Zhu C, Artandi SE, Rudolph KL, Gottlieb GJ, Chin L, Alt FW, DePinho RA. Telomere dysfunction impairs DNA repair and enhances sensitivity to ionizing radiation. Nat Genet. 2000; 26:85-88.

118. Castella M, Puerto S, Creus A, Marcos R, Surralles J. Telomere length modulates human radiation sensitivity in vitro, Toxicol. Lett. 2007,172, 29e36. Toxicol Lett. 2007; 172:29-36.

119. Berardinelli F, Nieri D, Sgura A, Tanzarella C, Antoccia A. Telomere loss, not average telomere length, confers radiosensitivity to TK6-irradiated cells. Mutat Res. 2012; 740:13-20.

120. Zhong YH, Liao ZK, Zhou FX, Xie CH, Xiao CY, Pan DF, Luo ZG, Liu SQ, Zhou YF. Telomere length inversely correlates with radiosensitivity in human carcinoma cells with the same tissue background. Biochem Biophys Res Commun. 2008; 367:84-89.

121. Cabuy E, Newton C, Joksic G, Woodbine L, Koller B, Jeggo PA, Slijepcevic P. Accelerated telomere shortening and telomere abnormalities in radiosensitive cell lines. Radiat Res. 2005; 164:53-62.

122. Latre L, Tusell L, Martin M, Miro R, Egozcue J, Blasco MA, Genesca A. Shortened telomeres join to DNA breaks interfering with their correct repair. Exp Cell Res. 2003; 287:282-88.

123. Drissi R, Wu J, Hu Y, Bockhold C, Dome JS. Telomere shortening alters the kinetics of the DNA damage response after ionizing radiation in human cells. Cancer Prev Res (Phila). 2011; 4:1973-81.

124. Goytisolo FA, Samper E, Martin-Caballero J, Finnon P, Herrera E, Flores JM, Bouffler SD, Blasco MA. Short telomeres result in organismal hypersensitivity to ionizing radiation in mammals. J Exp Med. 2000; 192:1625-36.

125. Sabatier L, Ricoul M, Pottier G, Murnane JP. The loss of a single telomere can result in instability of multiple chromosomes in a human tumor cell line. Mol Cancer Res. 2005; 3:139-50.

126. Li GZ, Eller MS, Firoozabadi R, Gilchrest BA. Evidence that exposure of the telomere 3' overhang sequence induces senescence. Proc Natl Acad Sci USA. 2003; 100:527-31.

127. Saretzki G, Sitte N, Merkel U, Wurm RE, von Zglinicki T. Telomere shortening triggers a p53-dependent cell cycle arrest via accumulation of G-rich single stranded DNA fragments. Oncogene. 1999; 18:5148-58.

128. Gnanasekar M, Thirugnanam S, Zheng G, Chen A, Ramaswamy K. T-oligo induces apoptosis in advanced prostate cancer cells. Oligonucleotides. 2009; 19:287-92.

129. Rankin AM, Forman L, Sarkar S, Faller DV. Enhanced cytotoxicity from deoxyguanosine-enriched T-oligo in prostate cancer cells. Nucleic Acid Ther. 2013; 23:311-21.

130. Bates PJ, Laber DA, Miller DM, Thomas SD, Trent JO. Discovery and development of the G-rich oligonucleotide AS1411 as a novel treatment for cancer. Exp Mol Pathol. 2009; 86:151-64.

131. Puri N, Pitman RT, Mulnix RE, Erickson T, Iness AN, Vitali C, Zhao Y, Salgia R. Non-small cell lung cancer is susceptible to induction of DNA damage responses and inhibition of angiogenesis by telomere overhang oligonucleotides. Cancer Lett. 2014; 343:14-23.

132. Wojdyla L, Stone AL, Sethakorn N, Uppada SB, Devito JT, Bissonnette M, Puri N. T-oligo as an anticancer agent in colorectal cancer. Biochem Biophys Res Commun. 2014; 446:596-601.

133. Pitman RT, Wojdyla L, Puri N. Mechanism of DNA damage responses induced by exposure to an oligonucleotide homologous to the telomere overhang in melanoma. Oncotarget. 2013; 4:761-771. https://doi.org/10.18632/ oncotarget.1047.

134. Sarkar S, Faller DV. T-oligos inhibit growth and induce apoptosis in human ovarian cancer cells. Oligonucleotides. 2011; 21:47-53.

135. Longe HO, Romesser PB, Rankin AM, Faller DV, Eller MS, Gilchrest BA, Denis GV. Telomere homolog oligonucleotides induce apoptosis in malignant but not in normal lymphoid cells: mechanism and therapeutic potential. Int J Cancer. 2009; 124:473-82.

136. Sarkar S, Faller DV. Telomere-homologous G-rich oligonucleotides sensitize human ovarian cancer cells to 
TRAIL-induced growth inhibition and apoptosis. Nucleic Acid Ther. 2013; 23:167-74.

137. Uppada SB, Erickson T, Wojdyla L, Moravec DN, Song Z, Cheng J, Puri N. Novel delivery system for T-oligo using a nanocomplex formed with an alpha helical peptide for melanoma therapy. Int J Nanomedicine. 2014; 9:43-53.

138. Coleman C, Levine D, Kishore R, Qin G, Thorne T, Lambers E, Sasi SP, Yaar M, Gilchrest BA, Goukassian DA. Inhibition of melanoma angiogenesis by telomere homolog oligonucleotides. J Oncol. 2010; 2010:928628.

139. Weng D, Cunin MC, Song B, Price BD, Eller MS, Gilchrest BA, Calderwood SK, Gong J. Radiosensitization of mammary carcinoma cells by telomere homolog oligonucleotide pretreatment. Breast Cancer Res. 2010; 12:R71.

140. Crees Z, Girard J, Rios Z, Botting GM, Harrington K, Shearrow C, Wojdyla L, Stone AL, Uppada SB, Devito JT, Puri N. Oligonucleotides and G-quadruplex stabilizers: targeting telomeres and telomerase in cancer therapy. Curr Pharm Des. 2014; 20:6422-37.

141. Burger AM, Dai F, Schultes CM, Reszka AP, Moore MJ, Double JA, Neidle S. The G-quadruplex-interactive molecule BRACO-19 inhibits tumor growth, consistent with telomere targeting and interference with telomerase function. Cancer Res. 2005; 65:1489-96.

142. Merle P, Gueugneau M, Teulade-Fichou MP, MullerBarthelemy M, Amiard S, Chautard E, Guetta C, Dedieu V, Communal Y, Mergny JL, Gallego M, White C, Verrelle P, Tchirkov A. Highly efficient radiosensitization of human glioblastoma and lung cancer cells by a G-quadruplex DNA binding compound. Sci Rep. 2015; 5:16255.

143. Bertrand H, Monchaud D, De Cian A, Guillot R, Mergny JL, Teulade-Fichou MP. The importance of metal geometry in the recognition of G-quadruplex-DNA by metal-terpyridine complexes. Org Biomol Chem. 2007; 5:2555-59.

144. Bertrand H, Bombard S, Monchaud D, Talbot E, Guedin A, Mergny JL, Grunert R, Bednarski PJ, Teulade-Fichou MP. Exclusive platination of loop adenines in the human telomeric G-quadruplex. Org Biomol Chem. 2009; 7:2864-71.

145. Trajkovski M, Morel E, Hamon F, Bombard S, TeuladeFichou MP, Plavec J. Interactions of Pt-ttpy with G-Quadruplexes Originating from Promoter Region of the c-myc Gene Deciphered by NMR and Gel Electrophoresis Analysis. Chemistry. 2015; 21:7798-807.

146. Merle P, Evrard B, Petitjean A, Lehn JM, Teulade-Fichou MP, Chautard E, De Cian A, Guittat L, Tran PL, Mergny JL, Verrelle P, Tchirkov A. Telomere targeting with a new G4 ligand enhances radiation-induced killing of human glioblastoma cells. Mol Cancer Ther. 2011; 10:1784-95.

147. Gowan SM, Heald R, Stevens MF, Kelland LR. Potent inhibition of telomerase by small-molecule pentacyclic acridines capable of interacting with G-quadruplexes. Mol Pharmacol. 2001; 60:981-88.
148. Leonetti C, Amodei S, D'Angelo C, Rizzo A, Benassi B, Antonelli A, Elli R, Stevens MF, D'Incalci M, Zupi G, Biroccio A. Biological activity of the G-quadruplex ligand RHPS4 (3,11-difluoro-6,8,13-trimethyl-8H-quino[4,3,2-k1] acridinium methosulfate) is associated with telomere capping alteration. Mol Pharmacol. 2004; 66:1138-46.

149. Salvati E, Leonetti C, Rizzo A, Scarsella M, Mottolese M, Galati R, Sperduti I, Stevens MF, D'Incalci M, Blasco M, Chiorino G, Bauwens S, Horard B, et al. Telomere damage induced by the G-quadruplex ligand RHPS4 has an antitumor effect. J Clin Invest. 2007; 117:3236-47.

150. Berardinelli F, Siteni S, Tanzarella C, Stevens MF, Sgura A, Antoccia A. The G-quadruplex-stabilising agent RHPS4 induces telomeric dysfunction and enhances radiosensitivity in glioblastoma cells. DNA Repair (Amst). 2015; 25:104-15.

151. Zhou FX, Xiong J, Luo ZG, Dai J, Yu HJ, Liao ZK, Lei H, Xie $\mathrm{CH}$, Zhou YF. cDNA expression analysis of a human radiosensitive-radioresistant cell line model identifies telomere function as a hallmark of radioresistance. Radiat Res. 2010; 174:550-57.

152. Ferrandon S, Saultier P, Carras J, Battiston-Montagne P, Alphonse G, Beuve M, Malleval C, Honnorat J, Slatter T, Hung N, Royds J, Rodriguez-Lafrasse C, Poncet D. Telomere profiling: toward glioblastoma personalized medicine. Mol Neurobiol. 2013; 47:64-76.

153. Orun O, Tiber PM, Serakinci N. Partial knockdown of TRF2 increase radiosensitivity of human mesenchymal stem cells. Int J Biol Macromol. 2016; 90:53-58.

154. Yang X, Li Z, Yang L, Lei H, Yu H, Liao Z, Zhou F, Xie C, Zhou Y. Knockdown of telomeric repeat binding factor 2 enhances tumor radiosensitivity regardless of telomerase status. J Cancer Res Clin Oncol. 2015; 141:1545-52.

155. Tang T, Zhou FX, Lei H, Yu HJ, Xie CH, Zhou YF, Liu SQ. Increased expression of telomere-related proteins correlates with resistance to radiation in human laryngeal cancer cell lines. Oncol Rep. 2009; 21:1505-09.

156. Yang L, Wang W, Hu L, Yang X, Zhong J, Li Z, Yang H, Lei H, Yu H, Liao Z, Zhou F, Xie C, Zhou Y. Telomere-binding protein TPP1 modulates telomere homeostasis and confers radioresistance to human colorectal cancer cells. PLoS One. 2013; 8:e81034.

157. Qiang W, Wu Q, Zhou F, Xie C, Wu C, Zhou Y. Suppression of telomere-binding protein TPP1 resulted in telomere dysfunction and enhanced radiation sensitivity in telomerase-negative osteosarcoma cell line. Biochem Biophys Res Commun. 2014; 445:363-68.

158. Miyake Y, Nakamura M, Nabetani A, Shimamura S, Tamura M, Yonehara S, Saito M, Ishikawa F. RPA-like mammalian Ctc1-Stn1-Ten1 complex binds to single-stranded DNA and protects telomeres independently of the Pot1 pathway. Mol Cell. 2009; 36:193-206.

159. Surovtseva YV, Churikov D, Boltz KA, Song X, Lamb JC, Warrington R, Leehy K, Heacock M, Price CM, Shippen 
DE. Conserved telomere maintenance component 1 interacts with STN1 and maintains chromosome ends in higher eukaryotes. Mol Cell. 2009; 36:207-18.

160. Chen LY, Redon S, Lingner J. The human CST complex is a terminator of telomerase activity. Nature. 2012; 488:540-44.

161. Luo YM, Xia NX, Yang L, Li Z, Yang H, Yu HJ, Liu Y, Lei H, Zhou FX, Xie CH, Zhou YF. CTC1 increases the radioresistance of human melanoma cells by inhibiting telomere shortening and apoptosis. Int J Mol Med. 2014; 33:1484-90.

162. Jin S, Weaver DT. Double-strand break repair by Ku70 requires heterodimerization with $\mathrm{Ku} 80$ and DNA binding functions. EMBO J. 1997; 16:6874-85.

163. Ramsden DA, Gellert M. Ku protein stimulates DNA end joining by mammalian DNA ligases: a direct role for $\mathrm{Ku}$ in repair of DNA double-strand breaks. EMBO J. 1998; 17:609-14.

164. Polotnianka RM, Li J, Lustig AJ. The yeast Ku heterodimer is essential for protection of the telomere against nucleolytic and recombinational activities. Curr Biol. 1998; 8:831-34.

165. Yang QS, Gu JL, Du LQ, Jia LL, Qin LL, Wang Y, Fan FY. ShRNA-mediated Ku80 gene silencing inhibits cell proliferation and sensitizes to gamma-radiation and mitomycin C-induced apoptosis in esophageal squamous cell carcinoma lines. J Radiat Res. 2008; 49:399-407.

166. Hu L, Wu QQ, Wang WB, Jiang HG, Yang L, Liu Y, Yu HJ, Xie CH, Zhou YF, Zhou FX. Suppression of Ku80 correlates with radiosensitivity and telomere shortening in the U2OS telomerase-negative osteosarcoma cell line. Asian Pac J Cancer Prev. 2013; 14:795-99.

167. Muller S, Scaffidi P, Degryse B, Bonaldi T, Ronfani L, Agresti A, Beltrame M, Bianchi ME. New EMBO members' review: the double life of HMGB1 chromatin protein: architectural factor and extracellular signal. EMBO J. 2001; 20:4337-40.

168. Lotze MT, Tracey KJ. High-mobility group box 1 protein (HMGB1): nuclear weapon in the immune arsenal. Nat Rev Immunol. 2005; 5:331-42.

169. Ke S, Zhou F, Yang H, Wei Y, Gong J, Mei Z, Wu L, Yu H, Zhou Y. Downregulation of high mobility group box 1 modulates telomere homeostasis and increases the radiosensitivity of human breast cancer cells. Int J Oncol. 2015; 46:1051-58.

170. Mahmoudi S, Henriksson S, Farnebo L, Roberg K, Farnebo M. WRAP53 promotes cancer cell survival and is a potential target for cancer therapy. Cell Death Dis. 2011; 2:e114.

171. Stern JL, Zyner KG, Pickett HA, Cohen SB, Bryan TM. Telomerase recruitment requires both TCAB1 and Cajal bodies independently. Mol Cell Biol. 2012; 32:2384-95.

172. Venteicher AS, Artandi SE. TCAB1: driving telomerase to Cajal bodies. Cell Cycle. 2009; 8:1329-31.
173. Zhong F, Savage SA, Shkreli M, Giri N, Jessop L, Myers T, Chen R, Alter BP, Artandi SE. Disruption of telomerase trafficking by TCAB1 mutation causes dyskeratosis congenita. Genes Dev. 2011; 25:11-16.

174. Qiu H, Zhao DY, Yuan LM, Zhang G, Xie CH. Regulatory effects of WRAP53 on radiosensitivity of laryngeal squamous cell carcinoma cells. Asian Pac J Cancer Prev. 2015; 16:2975-79.

175. Baerlocher GM, Oppliger Leibundgut E, Ottmann OG, Spitzer G, Odenike O, McDevitt MA, Roth A, Daskalakis M, Burington B, Stuart M, Snyder DS. Telomerase Inhibitor Imetelstat in Patients with Essential Thrombocythemia. N Engl J Med. 2015; 373:920-28.

176. Wu X, Smavadati S, Nordfjall K, Karlsson K, Qvarnstrom F, Simonsson M, Bergqvist M, Gryaznov S, Ekman S, Paulsson-Karlsson Y. Telomerase antagonist imetelstat inhibits esophageal cancer cell growth and increases radiation-induced DNA breaks. Biochim Biophys Acta. 2012; 1823:2130-35.

177. Hochreiter AE, Xiao H, Goldblatt EM, Gryaznov SM, Miller KD, Badve S, Sledge GW, Herbert BS. Telomerase template antagonist GRN163L disrupts telomere maintenance, tumor growth, and metastasis of breast cancer. Clin Cancer Res. 2006; 12:3184-92.

178. Marian CO, Wright WE, Shay JW. The effects of telomerase inhibition on prostate tumor-initiating cells. Int J Cancer. 2010; 127:321-31.

179. Marian CO, Cho SK, McEllin BM, Maher EA, Hatanpaa KJ, Madden CJ, Mickey BE, Wright WE, Shay JW, Bachoo RM. The telomerase antagonist, imetelstat, efficiently targets glioblastoma tumor-initiating cells leading to decreased proliferation and tumor growth. Clin Cancer Res. 2010; 16:154-63.

180. Shammas MA, Koley H, Bertheau RC, Neri P, Fulciniti M, Tassone P, Blotta S, Protopopov A, Mitsiades C, Batchu RB, Anderson KC, Chin A, Gryaznov S, Munshi NC. Telomerase inhibitor GRN163L inhibits myeloma cell growth in vitro and in vivo. Leukemia. 2008; 22:1410-18.

181. Wu X, Zhang J, Yang S, Kuang Z, Tan G, Yang G, Wei Q, Guo Z. Telomerase antagonist imetelstat increases radiation sensitivity in esophageal squamous cell carcinoma. Oncotarget. 2017; 8:13600-13610. https://doi.org/10.18632/ oncotarget.14618.

182. Gomez-Millan J, Goldblatt EM, Gryaznov SM, Mendonca MS, Herbert BS. Specific telomere dysfunction induced by GRN163L increases radiation sensitivity in breast cancer cells. Int J Radiat Oncol Biol Phys. 2007; 67:897-905.

183. Ferrandon S, Malleval C, El Hamdani B, BattistonMontagne P, Bolbos R, Langlois JB, Manas P, Gryaznov SM, Alphonse G, Honnorat J, Rodriguez-Lafrasse C, Poncet D. Telomerase inhibition improves tumor response to radiotherapy in a murine orthotopic model of human glioblastoma. Mol Cancer. 2015; 14:134. 
184. Ji XM, Xie CH, Fang MH, Zhou FX, Zhang WJ, Zhang MS, Zhou YF. Efficient inhibition of human telomerase activity by antisense oligonucleotides sensitizes cancer cells to radiotherapy. Acta Pharmacol Sin. 2006; 27:1185-91.

185. Yu C, Yu Y, Xu Z, Li H, Yang D, Xiang M, Zuo Y, Li $\mathrm{S}$, Chen $\mathrm{Z}, \mathrm{Yu} \mathrm{Z}$. Antisense oligonucleotides targeting human telomerase mRNA increases the radiosensitivity of nasopharyngeal carcinoma cells. Mol Med Rep. 2015; 11:2825-30.

186. Gao K, Li G, Qu Y, Wang M, Cui B, Ji M, Shi B, Hou P. TERT promoter mutations and long telomere length predict poor survival and radiotherapy resistance in gliomas. Oncotarget. 2016; 7:8712-8725. https://doi.org/10.18632/ oncotarget. 6007 .

187. Hauguel T, Bunz F. Haploinsufficiency of hTERT leads to telomere dysfunction and radiosensitivity in human cancer cells. Cancer Biol Ther. 2003; 2:679-84.

188. Chen M, Xing LN. siRNA-mediated inhibition of hTERC enhances radiosensitivity of cervical cancer. Asian Pac J Cancer Prev. 2012; 13:5975-79.

189. Zhang W, Xing L. RNAi gene therapy of SiHa cells via targeting human TERT induces growth inhibition and enhances radiosensitivity. Int J Oncol. 2013; 43:1228-34.

190. Nakamura M, Masutomi K, Kyo S, Hashimoto M, Maida Y, Kanaya T, Tanaka M, Hahn WC, Inoue M. Efficient inhibition of human telomerase reverse transcriptase expression by RNA interference sensitizes cancer cells to ionizing radiation and chemotherapy. Hum Gene Ther. 2005; 16:859-68

191. Qiu HB, Zhou YF, Zhou FX, Xie CH, Luo ZG, Yu HJ, Liu SQ. [Effective inhibition of hTERT expression by RNA interference on the radiosensitivity of human laryngeal cancer Hep-2 cell line]. Zhonghua Zhong Liu Za Zhi. 2007; 29:9-13.

192. Hu L, Zhou FX, Lei H, Zhang X, Qiu H, Dai J, Huang C, Xie C, Liu S, Zhou YF. Effect of shRNA inhibiting hTERT gene expression combined with $\lambda$-irradiation on human laryngeal cancer cells. Chinese Journal of Radiological Medicine and Protection. 2009; 29:253-58.

193. Zaffaroni N, Pennati M, Daidone MG. Survivin as a target for new anticancer interventions. J Cell Mol Med. 2005; 9:360-72.

194. Li F. Role of survivin and its splice variants in tumorigenesis. Br J Cancer. 2005; 92:212-16.

195. Wang R, Lin F, Wang X, Gao P, Dong K, Wei SH, Cheng SY, Zhang HZ. The therapeutic potential of survivin promoter-driven siRNA on suppressing tumor growth and enhancing radiosensitivity of human cervical carcinoma cells via downregulating hTERT gene expression. Cancer Biol Ther. 2007; 6:1295-301.

196. Okamoto Y, Ozaki T, Miyazaki K, Aoyama M, Miyazaki M, Nakagawara A. UbcH10 is the cancer-related E2 ubiquitinconjugating enzyme. Cancer Res. 2003; 63:4167-73.
197. Xiong J, Sun WJ, Wang WF, Liao ZK, Zhou FX, Kong HY, $\mathrm{Xu}$ Y, Xie CH, Zhou YF. Novel, chimeric, cancer-specific, and radiation-inducible gene promoters for suicide gene therapy of cancer. Cancer. 2012; 118:536-48.

198. Xu Y, Hou J, Liu Z, Yu H, Sun W, Xiong J, Liao Z, Zhou F, Xie C, Zhou Y. Gene therapy with tumor-specific promoter mediated suicide gene plus IL-12 gene enhanced tumor inhibition and prolonged host survival in a murine model of Lewis lung carcinoma. J Transl Med. 2011; 9:39.

199. Wang W, Yang L, Hu L, Li F, Ren L, Yu H, Liu Y, Xia L, Lei H, Liao Z, Zhou F, Xie C, Zhou Y. Inhibition of UBE2D3 expression attenuates radiosensitivity of MCF-7 human breast cancer cells by increasing hTERT expression and activity. PLoS One. 2013; 8:e64660.

200. Gao X, Wang W, Yang H, Wu L, He Z, Zhou S, Zhao H, Fu Z, Zhou F, Zhou Y. UBE2D3 gene overexpression increases radiosensitivity of EC109 esophageal cancer cells in vitro and in vivo. Oncotarget. 2016; 7:32543-32553. https://doi. org/10.18632/oncotarget.8869.

201. Cook BD, Dynek JN, Chang W, Shostak G, Smith S. Role for the related poly(ADP-Ribose) polymerases tankyrase 1 and 2 at human telomeres. Mol Cell Biol. 2002; 22:332-42.

202. Riffell JL, Lord CJ, Ashworth A. Tankyrase-targeted therapeutics: expanding opportunities in the PARP family. Nat Rev Drug Discov. 2012; 11:923-36.

203. Waaler J, Machon O, Tumova L, Dinh H, Korinek V, Wilson SR, Paulsen JE, Pedersen NM, Eide TJ, Machonova O, Gradl D, Voronkov A, von Kries JP, Krauss S. A novel tankyrase inhibitor decreases canonical Wnt signaling in colon carcinoma cells and reduces tumor growth in conditional APC mutant mice. Cancer Res. 2012; 72:2822-32.

204. Dregalla RC, Zhou J, Idate RR, Battaglia CL, Liber HL, Bailey SM. Regulatory roles of tankyrase 1 at telomeres and in DNA repair: suppression of T-SCE and stabilization of DNA-PKcs. Aging (Albany NY). 2010; 2:691-708. https:// doi.org/10.18632/aging.100210.

205. Lu ZX, Ye M, Yan GR, Li Q, Tang M, Lee LM, Sun LQ, Cao Y. Effect of EBV LMP1 targeted DNAzymes on cell proliferation and apoptosis. Cancer Gene Ther. 2005; 12:647-54.

206. Yang L, Xu Z, Liu L, Luo X, Lu J, Sun L, Cao Y. Targeting EBV-LMP1 DNAzyme enhances radiosensitivity of nasopharyngeal carcinoma cells by inhibiting telomerase activity. Cancer Biol Ther. 2014; 15:61-68.

207. Chen Y, Zhang Y. Functional and mechanistic analysis of telomerase: an antitumor drug target. Pharmacol Ther. 2016; 163:24-47.

208. Park SE, Park C, Kim SH, Hossain MA, Kim MY, Chung HY, Son WS, Kim GY, Choi YH, Kim ND. Korean red ginseng extract induces apoptosis and decreases telomerase activity in human leukemia cells. J Ethnopharmacol. 2009; 121:304-12.

209. Kim YJ, Kwon HC, Ko H, Park JH, Kim HY, Yoo JH, Yang HO. Anti-tumor activity of the ginsenoside Rk1 in 
human hepatocellular carcinoma cells through inhibition of telomerase activity and induction of apoptosis. Biol Pharm Bull. 2008; 31:826-30.

210. You JS, Hau DM, Chen KT, Huang HF. Combined Effects of Ginseng and Radiotherapy on Experimental Liver Cancer. Phytother Res. 1995; 9:331-35.

211. Arichi H, Kimura Y, Okuda H, Baba K, Kozawa M, Arichi S. Effects of stilbene components of the roots of Polygonum cuspidatum Sieb. et Zucc. on lipid metabolism. Chem Pharm Bull (Tokyo). 1982; 30:1766-70.

212. Ray PS, Maulik G, Cordis GA, Bertelli AA, Bertelli A, Das DK. The red wine antioxidant resveratrol protects isolated rat hearts from ischemia reperfusion injury. Free Radic Biol Med. 1999; 27:160-69.

213. Yang Y, Huang X, Chen S, Ma G, Zhu M, Yan F, Yu J. Resveratrol induced apoptosis in human gastric carcinoma SGC-7901 cells via activation of mitochondrial pathway. Asia Pac J Clin Oncol. 2018; 14:1-8.

214. Lanzilli G, Fuggetta MP, Tricarico M, Cottarelli A, Serafino A, Falchetti R, Ravagnan G, Turriziani M, Adamo R, Franzese O, Bonmassar E. Resveratrol down-regulates the growth and telomerase activity of breast cancer cells in vitro. Int J Oncol. 2006; 28:641-48.

215. Ko JH, Sethi G, Um JY, Shanmugam MK, Arfuso F, Kumar AP, Bishayee A, Ahn KS. The Role of Resveratrol in Cancer Therapy. Int J Mol Sci. 2017; 18:E2589.

216. Fuggetta MP, Lanzilli G, Tricarico M, Cottarelli A, Falchetti R, Ravagnan G, Bonmassar E. Effect of resveratrol on proliferation and telomerase activity of human colon cancer cells in vitro. J Exp Clin Cancer Res. 2006; 25:189-93.

217. Baatout S, Derradji H, Jacquet P, Mergeay M. Increased radiation sensitivity of an eosinophilic cell line following treatment with epigallocatechin-gallate, resveratrol and curcuma. Int J Mol Med. 2005; 15:337-52.

218. Luo H, Wang L, Schulte BA, Yang A, Tang S, Wang GY. Resveratrol enhances ionizing radiation-induced premature senescence in lung cancer cells. Int J Oncol. 2013; 43:1999-2006.

219. da Costa Araldi IC, Bordin FP, Cadona FC, Barbisan F, Azzolin VF, Teixeira CF, Baumhardt T, da Cruz IB, Duarte MM, Bauermann LF. The in vitro radiosensitizer potential of resveratrol on MCF-7 breast cancer cells. Chem Biol Interact. 2018; 282:85-92.

220. Lin SS, Lai KC, Hsu SC, Yang JS, Kuo CL, Lin JP, Ma YS, Wu CC, Chung JG. Curcumin inhibits the migration and invasion of human A549 lung cancer cells through the inhibition of matrix metalloproteinase-2 and -9 and Vascular Endothelial Growth Factor (VEGF). Cancer Lett. 2009; 285:127-33.

221. Wilken R, Veena MS, Wang MB, Srivatsan ES. Curcumin: A review of anti-cancer properties and therapeutic activity in head and neck squamous cell carcinoma. Mol Cancer. 2011; 10:12.
222. Zong H, Wang F, Fan QX, Wang LX. Curcumin inhibits metastatic progression of breast cancer cell through suppression of urokinase-type plasminogen activator by NF-kappa B signaling pathways. Mol Biol Rep. 2012; 39:4803-08.

223. Kim JM, Noh EM, Kwon KB, Kim JS, You YO, Hwang JK, Hwang BM, Kim BS, Lee SH, Lee SJ, Jung SH, Youn HJ, Lee YR. Curcumin suppresses the TPA-induced invasion through inhibition of PKC $\alpha$-dependent MMP-expression in MCF-7 human breast cancer cells. Phytomedicine. 2012; 19:1085-92.

224. Hassan ZK, Daghestani MH. Curcumin effect on MMPs and TIMPs genes in a breast cancer cell line. Asian Pac J Cancer Prev. 2012; 13:3259-64.

225. Lee WH, Loo CY, Young PM, Traini D, Mason RS, Rohanizadeh R. Recent advances in curcumin nanoformulation for cancer therapy. Expert Opin Drug Deliv. 2014; 11:1183-201.

226. Lee WH, Bebawy M, Loo CY, Luk F, Mason RS, Rohanizadeh R. Fabrication of Curcumin Micellar Nanoparticles with Enhanced Anti-Cancer Activity. J Biomed Nanotechnol. 2015; 11:1093-105.

227. Alibakhshi A, Ranjbari J, Arezumand R, PourhassanMoghaddam M, Rahmati M, Zarghami N, Namvaran MM. Curcuma longa extract inhibits telomerase activity in lung and breast cancer cells. Zahedan J Res Med Sci. 2014; 16:1-6.

228. Cui SX, Qu XJ, Xie YY, Zhou L, Nakata M, Makuuchi M, Tang W. Curcumin inhibits telomerase activity in human cancer cell lines. Int J Mol Med. 2006; 18:227-31.

229. Chakraborty S, Ghosh U, Bhattacharyya NP, Bhattacharya RK, Roy M. Inhibition of telomerase activity and induction of apoptosis by curcumin in K-562 cells. Mutat Res. 2006; 596:81-90.

230. Mukherjee Nee Chakraborty S, Ghosh U, Bhattacharyya NP, Bhattacharya RK, Dey S, Roy M. Curcumin-induced apoptosis in human leukemia cell HL-60 is associated with inhibition of telomerase activity. Mol Cell Biochem. 2007; 297:31-39.

231. Hsu FT, Liu YC, Liu TT, Hwang JJ. Curcumin Sensitizes Hepatocellular Carcinoma Cells to Radiation via Suppression of Radiation-Induced NF-кB Activity. Biomed Res Int. 2015; 2015:363671.

232. Lin JK, Liang YC. Cancer chemoprevention by tea polyphenols. Proc Natl Sci Counc Repub China B. 2000; 24:1-13.

233. Chen ZP, Schell JB, Ho CT, Chen KY. Green tea epigallocatechin gallate shows a pronounced growth inhibitory effect on cancerous cells but not on their normal counterparts. Cancer Lett. 1998; 129:173-79.

234. Wang YC, Bachrach U. The specific anti-cancer activity of green tea (-)-epigallocatechin-3-gallate (EGCG). Amino Acids. 2002; 22:131-43. 
235. Naasani I, Oh-Hashi F, Oh-Hara T, Feng WY, Johnston J, Chan K, Tsuruo T. Blocking telomerase by dietary polyphenols is a major mechanism for limiting the growth of human cancer cells in vitro and in vivo. Cancer Res. 2003; 63:824-30.

236. Naasani I, Seimiya H, Tsuruo T. Telomerase inhibition, telomere shortening, and senescence of cancer cells by tea catechins. Biochem Biophys Res Commun. 1998; 249:391-96.

237. Huang J, Chen S, Shi Y, Li CH, Wang XJ, Li FJ, Wang CH, Meng QH, Zhong JN, Liu M, Wang ZM. Epigallocatechin gallate from green tea exhibits potent anticancer effects in A-549 non-small lung cancer cells by inducing apoptosis, cell cycle arrest and inhibition of cell migration. J BUON. 2017; 22:1422-27.

238. Mittal A, Pate MS, Wylie RC, Tollefsbol TO, Katiyar SK. EGCG down-regulates telomerase in human breast carcinoma MCF-7 cells, leading to suppression of cell viability and induction of apoptosis. Int J Oncol. 2004; 24:703-10.

239. Lin SC, Li WC, Shih JW, Hong KF, Pan YR, Lin JJ. The tea polyphenols EGCG and EGC repress mRNA expression of human telomerase reverse transcriptase (hTERT) in carcinoma cells. Cancer Lett. 2006; 236:80-88.

240. Berletch JB, Liu C, Love WK, Andrews LG, Katiyar SK, Tollefsbol TO. Epigenetic and genetic mechanisms contribute to telomerase inhibition by EGCG. J Cell Biochem. 2008; 103:509-19.

241. Baatout S, Jacquet P, Derradji H, Ooms D, Michaux A, Mergeay M. Study of the combined effect of X-irradiation and epigallocatechin-gallate (a tea component) on the growth inhibition and induction of apoptosis in human cancer cell lines. Oncol Rep. 2004; 12:159-67.
242. Kwek JW, Iyer RB, Dunnington J, Faria S, Silverman PM. Spectrum of imaging findings in the abdomen after radiotherapy. AJR Am J Roentgenol. 2006; 187:1204-11.

243. Oeffinger KC, Mertens AC, Sklar CA, Kawashima T, Hudson MM, Meadows AT, Friedman DL, Marina N, Hobbie W, Kadan-Lottick NS, Schwartz CL, Leisenring W, Robison LL, and Childhood Cancer Survivor Study. Chronic health conditions in adult survivors of childhood cancer. N Engl J Med. 2006; 355:1572-82.

244. Oeffinger KC, Robison LL. Childhood cancer survivors, late effects, and a new model for understanding survivorship. JAMA. 2007; 297:2762-64.

245. Bonomo P, Loi M, Desideri I, Olmetto E, Delli Paoli C, Terziani F, Greto D, Mangoni M, Scoccianti S, Simontacchi G, Francolini G, Meattini I, Caini S, Livi L. Incidence of skin toxicity in squamous cell carcinoma of the head and neck treated with radiotherapy and cetuximab: A systematic review. Crit Rev Oncol Hematol. 2017; 120:98-110.

246. Lawrie TA, Green JT, Beresford M, Wedlake L, Burden S, Davidson SE, Lal S, Henson CC, Andreyev HJ. Interventions to reduce acute and late adverse gastrointestinal effects of pelvic radiotherapy for primary pelvic cancers. Cochrane Database Syst Rev. 2018; 1:CD012529.

247. Vonderheide RH, Hahn WC, Schultze JL, Nadler LM. The telomerase catalytic subunit is a widely expressed tumorassociated antigen recognized by cytotoxic T lymphocytes. Immunity. 1999; 10:673-79.

248. Kailashiya C, Sharma HB, Kailashiya J. Telomerase based anticancer immunotherapy and vaccines approaches. Vaccine. 2017; 35:5768-75.

249. Kyte JA. Cancer vaccination with telomerase peptide GV1001. Expert Opin Investig Drugs. 2009; 18:687-94. 